\title{
Neurodegeneration and Neuroprotection in Parkinson Disease
}

\author{
Stanley Fahn and David Sulzer \\ Department of Neurology, Columbia University, New York, New York 10032
}

\begin{abstract}
Summary: Many of the motoric features that define Parkinson disease (PD) result primarily from the loss of the neuromelanin (NM)-containing dopamine (DA) neurons of the substantia nigra ( $\mathrm{SN})$, and to a lesser extent, other mostly catecholaminergic neurons, and are associated with cytoplasmic "Lewy body" inclusions in some of the surviving neurons. While there are uncommon instances of familial PD, and rare instances of known genetic causes, the etiology of the vast majority of PD cases remains unknown (i.e., idiopathic). Here we outline ge-
\end{abstract}

netic and environmental findings related to PD epidemiology, suggestions that aberrant protein degradation may play a role in disease pathogenesis, and pathogenetic mechanisms including oxidative stress due to DA oxidation that could underlie the selectivity of neurodegeneration. We then outline potential approaches to neuroprotection for PD that are derived from current notions on disease pathogenesis. Key Words: PARK genes, alpha-synuclein, Parkin gene, ubiquitin pathway.

\section{CLINICAL, PATHOLOGICAL, AND BIOCHEMICAL OVERVIEW OF PD}

The term parkinsonism refers to a clinical syndrome comprising combinations of motor problems: bradykinesia (slowness and decreased amplitude of movement), tremor-at-rest, muscle rigidity, loss of postural reflexes, flexed posture, and the freezing phenomenon (where the feet are transiently "glued" to the ground). Not all six of these cardinal features need be present, but at least two should be before the diagnosis of parkinsonism is made, with at least one of them being tremor-at-rest or bradykinesia. Parkinson disease (PD) is the major cause of parkinsonism, and can also be referred to as primary parkinsonism, in contrast to the other three parkinsonian designations, ${ }^{1}$ namely 1) secondary, such as drug-induced parkinsonism and postencephalitic parkinsonism, 2) Parkinson-plus syndromes (presence of parkinsonism plus other neurological features), such as the diseases known as progressive supranuclear palsy and multiplesystem atrophy, and 3) heredodegenerative disorders in which parkinsonism is only one feature of a hereditary degenerative disorder, such as juvenile Huntington disease and Wilson disease. Three of the most helpful clues that indicate one is likely to be dealing with PD rather than another category of parkinsonism ${ }^{2}$ are 1) an asym-

Address correspondence and reprint requests to Stanley Fahn, M.D., Neurological Institute, 710 West 168 Street, New York, NY 10032. E-mail: fahn@neuro.columbia.edu. metrical onset of symptoms (PD often begins on one side of the body), 2) the presence of rest tremor (although rest tremor may be absent in patients with PD, it is almost always absent in Parkinson-plus syndromes), and 3) substantial clinical response to adequate levodopa therapy (usually, Parkinson-plus syndromes do not respond to levodopa therapy).

PD is a slowly progressive parkinsonian syndrome that begins insidiously, gradually worsens in severity, and, as described above, usually affects one side of the body before spreading to involve the other side. Rest tremor, because it is so obvious, is often the first symptom recognized by the patient. But the illness sometimes begins with bradykinesia, and in some patients, tremor may never develop. There is a steady worsening of symptoms over time, which, if untreated, leads to disability with severe immobility and falling. The early symptoms and signs of PD-rest tremor, bradykinesia, and rigidity - are usually correctable by treatment with levodopa and dopamine (DA) agonists. As PD progresses over time, symptoms that do not respond to levodopa develop, such as flexed posture, the freezing phenomenon, and loss of postural reflexes; these are often referred to as non-DA-related features of PD. Moreover, bradykinesia that responded to levodopa in the early stage of PD increases as the disease worsens and no longer fully responds to levodopa. It is particularly these intractable motoric symptoms that lead to the disability of increasing immobility and balance difficulties. 
While the motor symptoms of PD dominate the clinical picture, and even define the parkinsonian syndrome, many patients with PD have other complaints that have been classified as nonmotor. These include fatigue, depression, anxiety, sleep disturbances, constipation, bladder and other autonomic disturbances (sexual, gastrointestinal), sensory complaints, decreased motivation and apathy, slowness in thinking (bradyphrenia), and a declining cognition that can progress to dementia.

$\mathrm{PD}$ and the Parkinson-plus syndromes have in common a degeneration of substantia nigra (SN) pars compacta dopaminergic neurons, with a resulting deficiency of striatal DA concentration due to loss of the nigrostriatal neurons. Accompanying this neuronal loss is an increase in glial cells in the SN and a loss of neuromelanin $(\mathrm{NM})$, the pigment normally contained in SN dopaminergic neurons. In PD, intracytoplasmic eosinophilic inclusions called Lewy bodies are usually present in many of the surviving neurons. With the progressive loss of the nigrostriatal dopaminergic neurons, there is a corresponding decrease of DA content in both the SN and the striatum. The progressive loss of the dopaminergic nigrostriatal pathway can be detected during life using PET and SPECT scanning; these show a continuing reduction of fluoro-DOPA (FDOPA) and DA transporter ligand-binding in the striatum and also an altered secondary effect on cortical metabolism. ${ }^{3-7}$

\section{WHAT IS THE ROOT CAUSE OF PD? GENES VS. ENVIRONMENT}

\section{Correlation with age}

While PD is the most common neurodegenerative disorder after Alzheimer disease, its true presence in the population is difficult to ascertain. Age, nevertheless, is clearly the greatest factor in PD expression. A study of the northern Manhattan population indicates a prevalence (fraction of individuals that express the disease) of $0.1 \%$ of the total population. ${ }^{8}$ A European study of nearly 15,000 participants aged 65 and older ${ }^{9}$ reports that the prevalence of parkinsonism for 65- to 89-year-olds increased steadily from $0.6 \%$ to $3.5 \%$, (FIG. 1). In contrast, Alzheimer disease has a prevalence of $25 \%$ to $30 \%$ in patients aged 85 to 89 years. The correlation of PD and aging is even more striking from studies of disease incidence (the number of new cases per year) (FIG. 2). ${ }^{10} \mathrm{~A}$ meta-analysis of 25 incidence studies estimated an overall population incidence of $16-19$ per 100,000 per year, ${ }^{11}$ while a study of 4,500 randomly chosen Italians between 65 and 84 years of age estimated an incidence of 530 per 100,000 per year for parkinsonism and 326 per 100,000 per year for PD. ${ }^{12}$ The authors of the Italian study calculated that the risk for developing PD (the likelihood

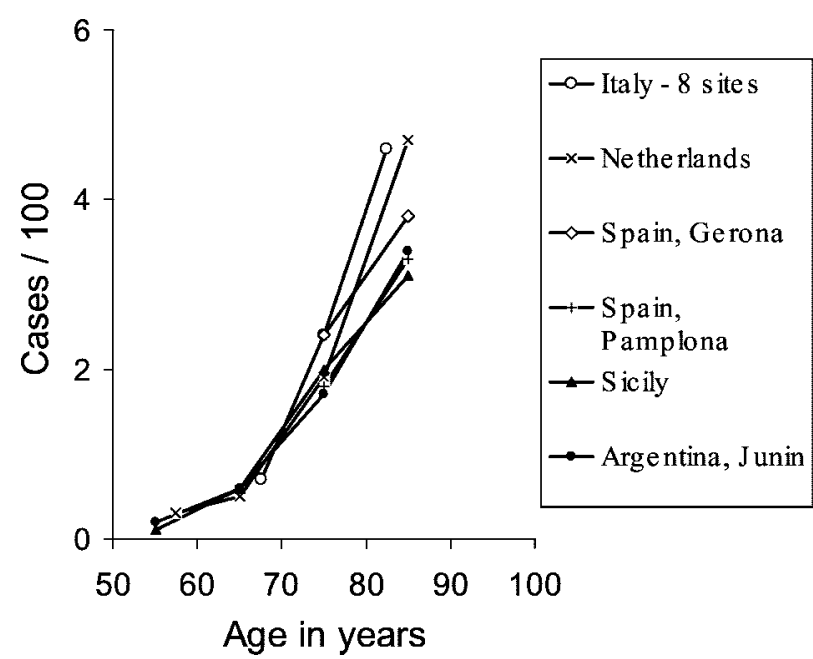

FIG. 1. Age-specific prevalence rates of PD in different countries. This figure is a modification of a figure in de Rijk et al., ${ }^{9}$ provided by W. A. Rocca (personal communication, 2003), along with permission to reproduce.

that an individual will develop the disease) was $1.1 \%$ per each subsequent year of age.

Even a clear correlation with aging and disease expression, however, is controversial, and it has been suggested that by some advanced age there is relatively little cumulative increase in PD. ${ }^{13}$ This issue is important, because ongoing loss of NM-containing SN neurons occurs in healthy people ${ }^{14}$ and there is a notion that PD is a disease of "accelerated aging" that all people would develop given sufficiently long lives. ${ }^{14-17}$ While by far the majority of PD cases are sporadic or idiopathic, meaning that the cause is unknown, and while aging provides the strongest known correlation, there are identifiable causes

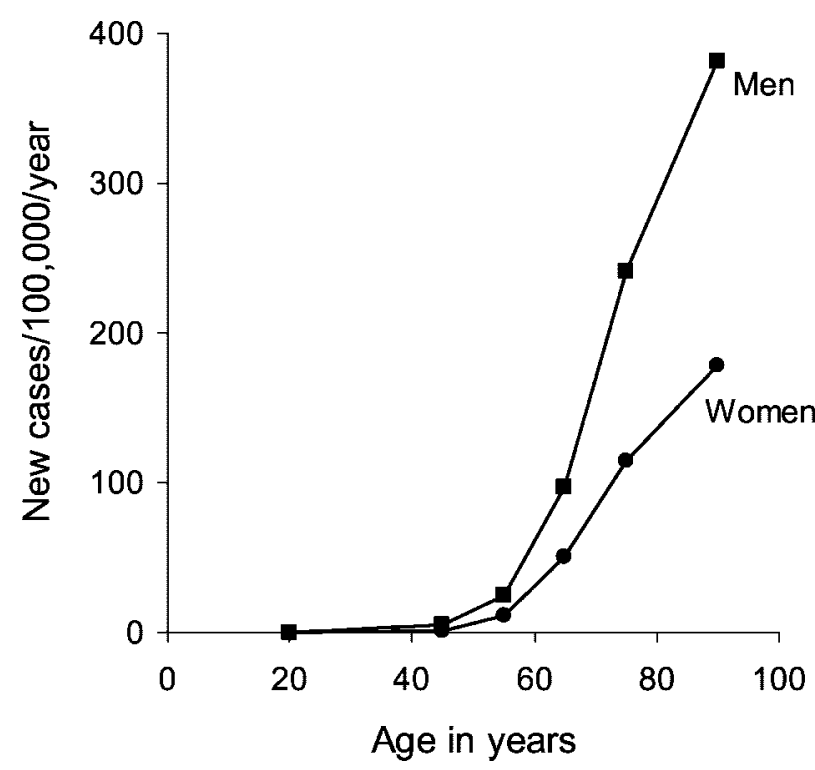

FIG. 2. Age- and sex-specific incidence of Parkinson disease. Data from Rochester, MN from 1975 to 1990. From Bower et al. ${ }^{10}$ with permission from the Movement Disorder Society. 


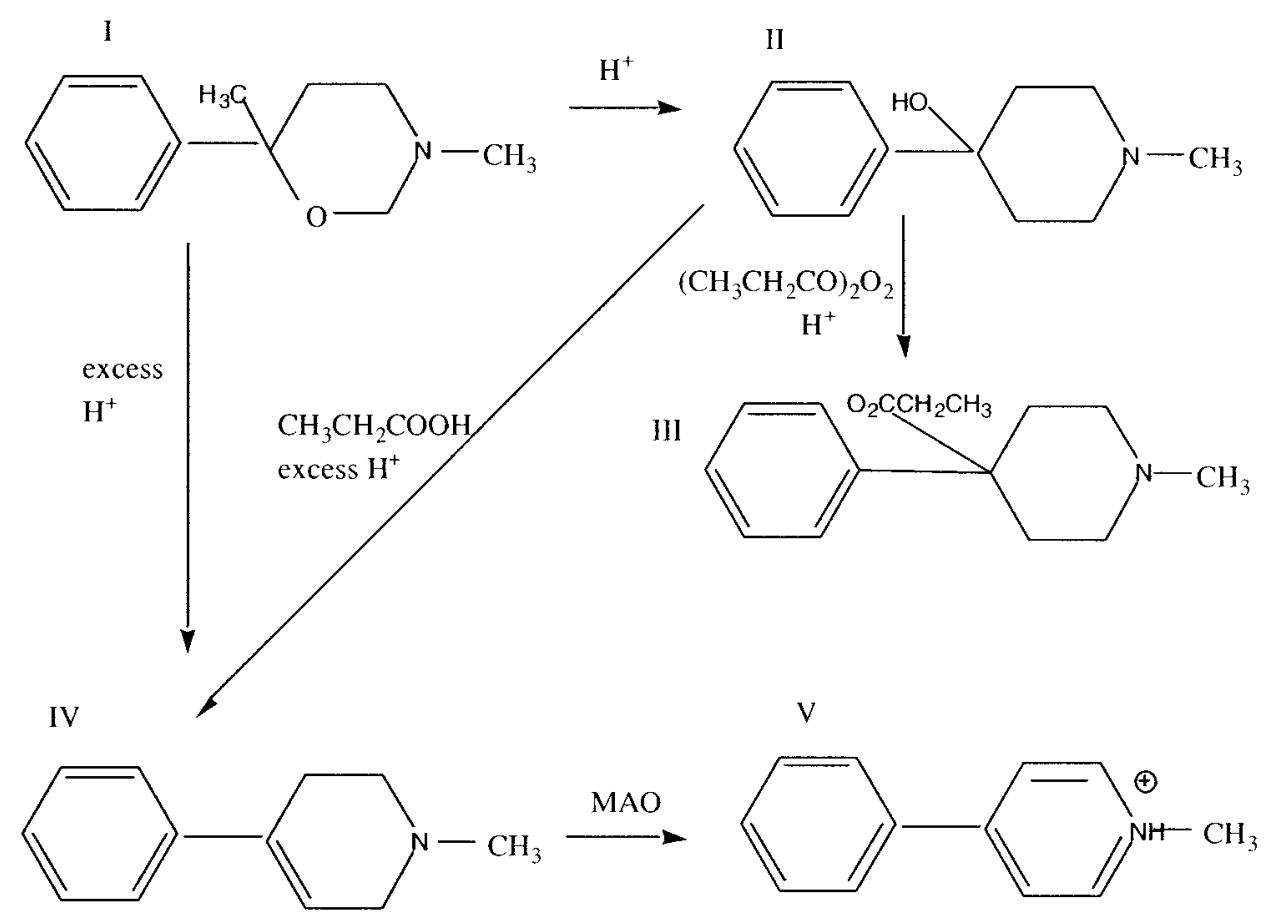

FIG. 3. MPTP (IV) is a byproduct sometimes formed in the illicit synthesis of MPPP (III), a narcotic that differs by a single methyl group from alphaprodine (1,3-dimethyl-4-phenyl-4-propionoxypiperidine; Nisentil). Compound I (3,6-dimethyl-6-phenyltetrahydro-1,3-oxazine), which can be produced from easily available ingredients, is treated with sulfuric or hydrochloric acid to produce II (1-methyl4-phenyl-4- propionoxypiperidine; also called HPMP in Davis et al. ${ }^{21}$ ). Compound II, when treated with propionic anhydride and sulfuric acid is converted to III (1-methyl-4-phenyl-4-propionoxypiperidine; MPPP; PPMP in Davis et al. ${ }^{21}$ ). Under excess acidity, ${ }^{20}$ in the presence of "wet" propionic anhydride, ${ }^{22}$ or in the presence of dehydrating reagents, ${ }^{19}$ II can be converted to IV, (1-methyl-4-phenyl1,2,5,6-tetrahydropyridine; MPTP; HPMP in Davis et al. ${ }^{21}$ ). Compound I can also be directly converted to MPTP in excess acid. ${ }^{20}$ Following entry into cells, monoamine oxidase (particularly MAO B, which is more highly expressed in astrocytes than DA neurons) in mitochondria converts MPTP (via conversion to 1-methyl-4-phenyl-2,3, dihydropyridinium; MPFP+, not shown) to V, MPP+ (1-methyl4-phenyl-1,2,5,6-tetrahydropyridinium), ${ }^{156}$ which is accumulated by catecholamine uptake transporters selectively into DA and other catecholamine neurons. ${ }^{157}$

for a small fraction of cases that would seem to argue against a simple model of accelerated aging. Moreover, the pattern of neuronal loss in the SN in patients with PD and in the normal aging population differs, ${ }^{18}$ again indicating that accelerated aging alone is not responsible for causing PD.

\section{Chemically induced parkinsonism and environmental factors}

The event that renewed the impetus suggesting that environmental factors may contribute to the etiology of PD was the recognition of a clearly induced state of acute parkinsonism by accidental poisoning from MPTP (1methyl-4-phenyl-1,2,5,6-tetrahydropyridine), an impurity that was a byproduct in batches of illicitly produced "synthetic heroin" MPPP (1-methyl-4-phenyl-4-propionoxypiperidine; also known as PPMP in Davis et al. ${ }^{21}$ ). Save the absence of an additional methyl group on the 4-phenyl-piperidine ring, MPPP is identical to the narcotic alphaprodine (1,3-dimethyl-4-phenyl-4-propionoxypiperidine; also known as Nisentil), which is 26-fold more potent in rats than its better known isomer, Demerol (meperidine; pethidine; 1-methyl-4-phenyl-4-piperidinecarboxylic acid ethyl ester). As a potent narcotic that can be produced from easily available ingredients, MPPP has been a popular drug for synthesis by clandestine laboratories. Two methods of manufacture were published, ${ }^{19,20}$ and both reported MPTP formation from compound II as shown in FIG. 3; Zeiring et al. ${ }^{19}$ state that MPTP has distinct morphine-like properties. Ironically, MPTP was briefly examined clinically in the 1950s as a potential treatment for PD and depression ${ }^{21}$ but was rapidly discounted due to toxicity in animal studies.

An initial clue to the presence of a parkinsonisminducing agent produced during MPPP synthesis was in a case report of a 23-year-old graduate student who used the Zeiring method and took the compound himself. ${ }^{21}$ The patient apparently reduced the reaction times and used higher reaction temperatures for MPPP synthesis and neglected to isolate and crystallize the compound properly. The authors of this initial report suggested that the toxic compound could have been MPTP. This patient died 2 years later from an apparent cocaine and codeine overdose, and neuropathological changes were characterized by loss of SN DA neurons, a Lewy body, and extracellular NM as well as NM within microglia. The authors imitated the patient's attempts at synthesis and 
found that treating compound I (FIG. 3) with propionic anhydride and sulfuric acid resulted in both MPPP (which they called PPMP) and MPTP (which they called DPMP), and suggested that these compounds were the cause of the disease. Another young addict was diagnosed with parkinsonism in Vancouver after attempting to make MPPP using the Schmidle method $^{20}$ with "wet" propionic anhydride, ${ }^{22}$ and a laboratory chemist who synthesized and handled this lipophilic toxin was similarly diagnosed. ${ }^{23}$ In 1982, several opiate addicts in San Jose and Watsonville, California developed PD symptoms within days of drug administration, and the identification of the pathogen as MPTP ${ }^{24}$ is the subject of an interesting detectivestyle popular science book..$^{25}$ The identification of MPTP as the culprit was confirmed using primates. ${ }^{26}$ Some of the California patients showed remarkable improvement a decade later from striatal transplants of SN fetal tissue. ${ }^{27}$

In addition to MPTP toxicity, there are also numerous reports suggesting roles for other compounds in the induction of parkinsonism; the best documented is manganese. ${ }^{28-30}$ Manganese toxicity also produces dystonia and was observed in manganese miners and ore-crushing workers. Toxicity from MPTP is much more specific, affecting selectively the DA neurons, than that from manganese, which affects other basal ganglia neurons. Although these and other chemical poisons, e.g., carbon monoxide, can induce parkinsonism, these conditions are classified as secondary parkinsonism, not primary or PD.

Rural living and pesticide and herbicide exposure have also been suggested from epidemiological studies to play a role in inducing PD. ${ }^{31}$ Strikingly, the animal model for PD which may best represent aspects of PD, including apparent Lewy bodies, uses exposure to the pesticide rotenone, an inhibitor of complex I in the mitochondrial oxidative phosphorylation pathway. ${ }^{32}$ This is one of the same targets that MPTP affects via its metabolite, $\mathrm{MPP}^{+}$. While the search continues for environmental factors that can be associated with PD, epidemiological studies have shown that cigarette smoking and coffee drinking are inversely associated with PD. ${ }^{33}$

\section{Familial PD and the PARK genes}

The great majority of cases of primary parkinsonism are sporadic, but a positive family history is seen in over $10 \%$ of cases. Nevertheless, a genetic basis for PD had long been controversial. Twin studies measuring concordance rates in monozygotic and dizygotic twins indicate that genetics plays a greater role in younger onset patients than in patients with onset greater than age 50 years. $^{34}$

In the last few years several gene mutations have been discovered by painstaking linkage and genome analysis to cause PD in a small number of families. Ten monogenic forms of PD, labeled PARK 1-10, have been identified (Table 1), with genes identified in five. They present either as autosomal dominants or autosomal re- cessives. The former are found in rare families. The autosomal recessives, particularly PARK2, are much more common, though still infrequent.

PARK1, the alpha-synuclein gene, was identified in 13 families. All but one carry a Ala53Thr substitution ${ }^{35}$ with the exception being a German family that carries an Ala30Pro substitution. ${ }^{36}$ These families show response to levodopa treatment and the clinical and neuropathological signs of PD. Indeed, the alpha-synuclein protein is a major constituent of Lewy bodies in both sporadic PD and PARK1 patients. ${ }^{37}$ Perhaps more surprising was that a truncated fragment known as the NAC fragment (for non-amyloid-component) is a major ingredient in Alzheimer plaques. ${ }^{38}$ Multiple proteins capable of binding alpha-synuclein have been identified, and at least one, known as synphilin, appears to also be localized in Lewy bodies. ${ }^{39}$ Consistent with aggregation into inclusions, alpha-synuclein, like $\beta$-amyloid, is prone to selfaggregation, although aggregation can be accelerated by transition metals, DA and likely some peptides and lipids, as well as a variety of sequence alterations. ${ }^{40-44}$

The normal biological roles for alpha-synuclein remain elusive, although it was described early on as a protein up-regulated during songbird learning periods. ${ }^{45}$ The name synuclein was chosen to describe its dual immunolabel sites in the nucleus and synapses. ${ }^{46}$ Presently, most researchers believe that this protein is natively unfolded but by virtue of containing an A2 alpha helix domain, can associate with vesicle membranes. ${ }^{45} \mathrm{~A}$ potential role for binding to synaptic vesicles is suggested by an enhanced synaptic recovery for evoked DA release in the knockout mouse ${ }^{47}$ and alterations in the distal synaptic vesicle pool in mutants. ${ }^{48,49}$ There are also suggestions that alpha-synuclein may regulate intracellular DA pools via effects on tyrosine hydroxylase or expression of the DA uptake transporter. ${ }^{50,51}$

The normal function of alpha-synuclein, however, may have little or nothing to do with its role in pathogenesis. Its ability to self-aggregate, its presence in Lewy bodies, the apparent ability of pathogenic mutations or nitrated or DA-reacted proteins to be more prone to aggregation, the ability of protofibrils forms to disrupt membrane, and the recent identification of PARK4 as a triplication of the chromosomal region that contains the alpha-synuclein gene, ${ }^{52}$ all seem to point to a toxic function of alphasynuclein itself. This notion is also supported by the finding that mice lines that lack alpha-synuclein expression are resistant to MPTP toxicity, although neuronal and synaptic vesicle uptake appears unaltered. ${ }^{53}$ Expression of mutant alpha-synuclein also causes an apparent increase in cytosolic DA levels, suggesting a link between genetic and oxidative stress pathways. ${ }^{54}$ Thus, it may be that the disease stems from inappropriate or dysregulated degradation of this protein.

It has been suggested that parkin is required for alpha- 
TABLE 1. Genetic Linkage and Gene Identification in PD

\begin{tabular}{|c|c|c|c|c|c|}
\hline Name and Locus & Gene & $\begin{array}{l}\text { Mode of Inheritance; } \\
\text { Pathological Features }\end{array}$ & Protein Function & Location & Pathogenic Mutations \\
\hline PARK1 4q21-q22 & Alpha-synuclein & $\begin{array}{l}\text { Autosomal dominant; } \\
\text { Lewy bodies }\end{array}$ & $\begin{array}{l}\text { Possibly synaptic } \\
\text { vesicle traffick- } \\
\text { ing; elevated } \\
\text { in birdsong } \\
\text { learning }\end{array}$ & $\begin{array}{l}13 \text { families in Germany, It- } \\
\text { aly (Contoursi kindred), } \\
\text { Greece }\end{array}$ & $\begin{array}{l}\text { A53T and A30P, may } \\
\text { promote aggrega- } \\
\text { tion; Lewy body } \\
\text { and Alzheimer } \\
\text { plaque component }\end{array}$ \\
\hline PARK2 6q25.2-q27 & Parkin & $\begin{array}{l}\text { Autosomal recessive (also } \\
\text { dominant?); often juve- } \\
\text { nile onset, no Lewy } \\
\text { bodies }\end{array}$ & $\begin{array}{l}\text { Ubiquitin E3 } \\
\text { ligase, attaches } \\
\text { short ubiquitin } \\
\text { peptide chains } \\
\text { to a range of } \\
\text { proteins, likely } \\
\text { to mark degra- } \\
\text { dation }\end{array}$ & $\begin{array}{l}\text { Ubiquitous, originally in } \\
\text { Japan, very common in } \\
\text { juvenile onset }\end{array}$ & $\begin{array}{l}\text { Over } 70 \text { mutations } \\
\text { identified; most } \\
\text { likely loss of func- } \\
\text { tion mutations }\end{array}$ \\
\hline PARK3 2p13 & Unknown & $\begin{array}{l}\text { Autosomal dominant; } \\
\text { Lewy bodies, indistin- } \\
\text { guishable from idio- } \\
\text { pathic PD }\end{array}$ & & $\begin{array}{l}\text { Four families in southern } \\
\text { Denmark and northern } \\
\text { Germany, probable com- } \\
\text { mon ancestor }\end{array}$ & \\
\hline PARK4 4q region & $\begin{array}{l}\text { Likely multiple } \\
\text { copies of } \\
\text { alpha- } \\
\text { synuclein }\end{array}$ & $\begin{array}{l}\text { Autosomal dominant; } \\
\text { wide range of symp- } \\
\text { toms from idiopathic } \\
\text { PD to dementia, Lewy } \\
\text { bodies }\end{array}$ & See PARK1 & $\begin{array}{l}\text { Spellman-Muenter and } \\
\text { Waters-Miller families } \\
\text { with common ancestor in } \\
\text { the United States; newly } \\
\text { identified European families }\end{array}$ & $\begin{array}{l}\text { Duplications and trip- } \\
\text { lications of chro- } \\
\text { mosomal region } \\
\text { that contains wild- } \\
\text { type alpha- } \\
\text { synuclein gene }\end{array}$ \\
\hline PARK5 4p14 & $\begin{array}{l}\text { Ubiquitin C- } \\
\text { terminal } \\
\text { hydrolase L1 }\end{array}$ & $\begin{array}{l}\text { Possibly autosomal domi- } \\
\text { nant }\end{array}$ & $\begin{array}{l}\text { Removes poly- } \\
\text { ubiquitin }\end{array}$ & One family in Germany & \\
\hline PARK6 1p35-p36 & Unknown & $\begin{array}{l}\text { Autosomal recessive; } \\
\text { juvenile onset }\end{array}$ & & One family in Sicily & \\
\hline PARK7 1p36 & DJ-1 & $\begin{array}{l}\text { Autosomal recessive; early } \\
\text { onset }\end{array}$ & $\begin{array}{l}\text { Sumoylation } \\
\text { pathway }\end{array}$ & $\begin{array}{l}\text { Families in Holland, Italy, } \\
\text { Uruguay }\end{array}$ & $\begin{array}{l}\text { L166P, M261, and a } \\
\text { variety of other } \\
\text { candidates }\end{array}$ \\
\hline $\begin{array}{l}\text { PARK8 12p11.2- } \\
\text { q13.1 }\end{array}$ & Unknown & $\begin{array}{l}\text { Autosomal dominant; } \\
\text { nigral degeneration, no } \\
\text { Lewy bodies }\end{array}$ & & One family in Japan & \\
\hline PARK9 1p36 & Unknown & $\begin{array}{l}\text { Autosomal recessive; } \mathrm{Ku}- \\
\text { for-Rakeb syndrome, a } \\
\text { Parkinson-plus disorder }\end{array}$ & & One family in Jordan & \\
\hline PARK10 1p32 & Unknown & $\begin{array}{l}\text { Autosomal recessive; late } \\
\text { onset }\end{array}$ & & Families in Iceland & \\
\hline
\end{tabular}

synuclein degradation, ${ }^{55}$ but the normal degradation pathway of the protein is unclear and evidence exists for both proteasome and lysosomal ("autophagic") pathways $^{43,56}$; it is possible that either can occur depending upon conditions. It is also not yet clear precisely why the pathogenic mutations might be less susceptible to degradation, and if this may also occur with modified alphasynuclein, such as the protofibril, nitrated, or DA-adduct forms, that may occur in idiopathic PD.

PARK2, the parkin gene, is inherited as an autosomal recessive trait, and differs from idiopathic $\mathrm{PD}$ in that it can have a juvenile onset and lack of Lewy bodies, although there is a progressive loss of SN neurons. Originally identified in Japan as a juvenile-onset PD without Lewy bodies, ${ }^{57}$ parkin mutations have now been identified pan-ethnically and are thought to be the cause of approximately $50 \%$ of familial young-onset PD and $15 \%$ to $20 \%$ of sporadic young-onset PD ( $<50$ years). Over 70 mutations, including exon rearrangements, point mutations, and deletions, have been identified, many of them recurrent in different populations. The identification of parkin mutations is inversely correlated with age of onset, with the earliest age of onset having the greatest association. However, PARK2 does not appear to be restricted to young-onset $\mathrm{PD}$, and parkin mutations have been identified in individuals over $50 .{ }^{58}$ Recent findings suggest that juvenile parkin-related PD is associated with mutations in both parkin alleles (homozygotes or compound heterozygotes). Some compound heterozygotes have now been recognized as having adult-onset PD with Lewy bodies. ${ }^{59}$

A single parkin mutation (heterozygote) may be re- 
sponsible for instances of later onset PD. ${ }^{60}$ This is a crucial finding in the search for the cause of idiopathic $\mathrm{PD}$, and it is clear that of all the loci and genes discovered to date, parkin plays an important role. The frequency and penetrance of parkin mutations have yet to be determined.

Parkin has been identified as an ubiquitin E3 ligase $^{61,62}$ that attaches short ubiquitin peptide chains to proteins, presumably involved in targeting these proteins for the ubiquitin/proteasome pathway of protein degradation. The mutations lead to loss of ubiquitinating function. A range of recent papers indicates protective functions of parkin expression due to the ubiquitination of various substrates. ${ }^{55,62,63}$ The implied role in formation of Lewy bodies by parkin as well as by PARK8 (juvenile patients with homozygous PARK2 mutations and heterozygous PARK8 patients lack Lewy bodies) remains unexplained.

PARK4, as mentioned above, appears due to duplications and/or triplications of regions on chromosome 4 that contain the gene for alpha-synuclein in addition, in the first reported case, to 17 other putative genes. ${ }^{52}$ It thus seems that overexpression of alpha-synuclein protein may produce PD, although this has yet to be demonstrated. The authors of the initial report suggest that the disease process may be analogous to the etiology of Alzheimer disease in Down syndrome, which is triggered by overexpression of the amyloid precursor protein due to chromosome 21 trisomy.

PARK5, ubiquitin-carboxy-terminal-hydrolase L1 (UCHL1) is an autosomal dominant mutation found in a single family. ${ }^{64}$ Mice with partial gene deletions display neurodegeneration of sensory and motor neurons and accumulate ubiquitin and proteasome-labeled inclusion bodies.

PARK7, the DJ-1 gene, is another early-onset autosomal recessive mutation independently confirmed in a Dutch family and families in Italy and Uruguay. ${ }^{65}$ PARK7 is characterized by slow progression and a good response to levodopa. The DJ-1 protein is involved in sumoylation (SUMO, small ubiquitin-like modifier), a pathway similar to ubiquitination involved in targeting proteins for degradation as well as nuclear transport, transcriptional regulation, and apoptosis. ${ }^{66}$ DJ-1 appears to act on mRNA expression by interacting with PIASx alpha, an E3 ubiquitin-like enzyme reminiscent of parkin that adds SUMO-1 to target proteins. ${ }^{67}$ The L166P mutation of DJ-1 causes mislocalization to mitochondria in vitro. ${ }^{65}$ Paraquat induces an acidic isoform of DJ-1, perhaps indicating a relationship between energy dysfunction and genetic mechanisms of PD pathogenesis. ${ }^{68}$

There are likely additional multiple alleles that have yet escaped detection that at least predispose humans to PD. Together, the identification of these mutant genes and proteins is contributing more to understanding PD than might be expected from their low fraction of repre- sentation in the disease. One of the most striking points is that parkin, UCHL1, and DJ-1 may all be related to ubiquitin/proteasomal protein degradation. Overall, these pathogenic mutations have promulgated the idea that the ultimate cause of PD is either a failure of the ubiquitination/protein degradation machinery or dangerous protein aggregates. A critique of these hypotheses, however, is that neither idea in itself explains the neuronal specificity of the disease. They also stand in apparent contrast to the MPTP model, which suggests an ultimate role for energy loss. While the identification of the mutants would seem to favor "the gene vs. the environment" as the cause of the disease, the MPTP story needs to be kept in mind, as well as the low penetrance of some of the mutations and less than complete concordance in monozygotic disease.

\section{WHY IS PD SO SELECTIVE FOR SOME NEURONS?}

Here we mention current hypotheses that may explain the initial selective toxic insult in PD. These include possible roles for protein aggregation, oxidative stress, and protein degradation. These pathways obviously exhibit elaborate reciprocal effects, and no one pathway need preclude another.

\section{Protein aggregation}

Areas showing neuronal loss in PD are the large NMcontaining SN neurons, the locus ceruleus, the dorsal motor nucleus of the vagus, basal nucleus of Meynert, and peripheral catecholaminergic neurons. In all areas, these are accompanied by the presence of Lewy bodies. The Lewy bodies are extraordinarily large intracytoplasmic inclusions, meaning that they lack a limiting membrane, and have apparent "halos" and cores (FIG. 4). They are highly ubiquitinated and contain high levels of alpha-synuclein, particularly in the halo; many other proteins have been suggested to be present by immunolabel, including parkin and torsinA. It should be noted that these structures may be fairly "sticky" and some of these candidate proteins may later be disproved by physiochemical analysis methods. Despite their size, it is by no means clear if Lewy bodies are involved in PD pathogenesis or simply a consequence of it, or even a desperate protective attempt by the neuron. Such an aggregation of non-degraded cytosolic protein and subsequent translocation to the perinuclear centrosomal region is characterized as the "aggresome" hypothesis, ${ }^{69}$ and such a role has already been implicated for both synuclein and parkin degradation. ${ }^{70,71}$ Because juvenile PD patients do not have Lewy bodies due to PARK2 mutations, it is unlikely that the Lewy body is the cause of neuronal degeneration in the SN.

An alternate theory is that before the formation of 


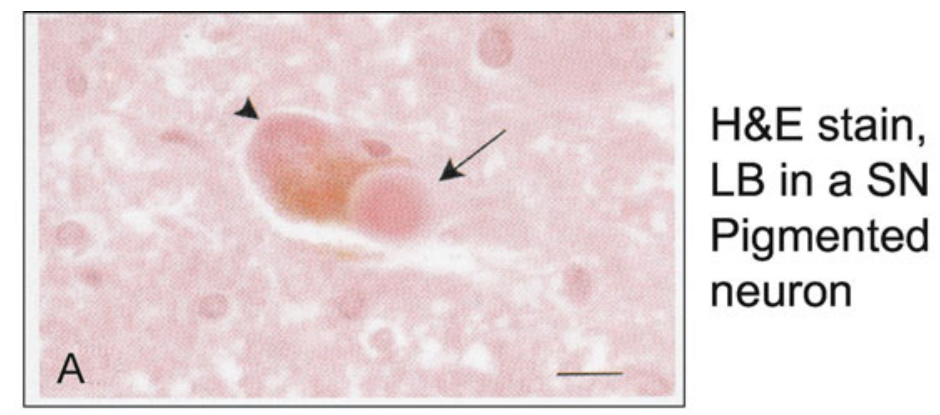

Lewy Bodies

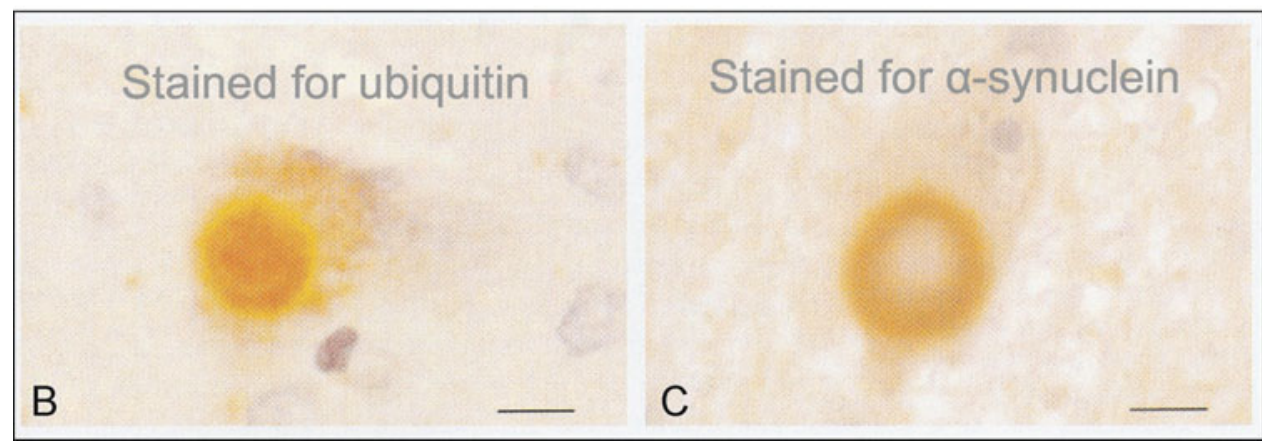

FIG. 4. Histopathology of Lewy bodies (LB), from Duyckaerts. ${ }^{158} \mathrm{~A}$ : LB (arrow) in a pigmented neuron, showing dense central core and peripheral halo of the LB when stained with hematoxylin and eosin stain; the arrowhead points to neuromelanin within the cell. B: Immunostaining for ubiquitin reveals the presence of this protein within the central core of the LB. C: Immunostaining for alpha-synuclein reveals the presence of this protein within the surrounding halo of the LB. From Duyckaerts C. Les corps et prolongements de Lewy. Rev Neurol (Paris) 156:800-801. Copyright (C) Masson, Paris, 2000. All rights reserved.

large aggregates, alpha-synuclein forms small oligomers known as protofibrils and fibrils. ${ }^{72}$ Protofibrils form pores, at least in artificial membranes, that can collapse ion gradients. $^{72}$ Both MPTP and paraquat result in synuclein aggregation. Strikingly, DA-quinone can stabilize the protofibril form in vitro ${ }^{41}$; if this enhancement of protofibrils also occurs in neurons, it may unify two major hypotheses of PD pathogenesis, a role for reactive DA with alpha-synuclein expression.

\section{Dysregulation of neuronal DA pools and oxidative stress}

Models using administration of MPTP to mice and primates or MPP+ to neuronal cultures have shown that MPP+ is specifically accumulated into DA neurons as a substrate for the DA uptake transporter (DAT) ${ }^{73}$ while mice with deleted DAT are resistant to both $\mathrm{MPTP}^{74}$ and methamphetamine neurotoxicity. ${ }^{75} \mathrm{MPP}+$, once inside the neuron, depresses mitochondrial oxidative phosphorylation by inhibiting complex I. ${ }^{76,77}$ This would decrease ATP, which would be expected to produce many downstream consequences. One site susceptible for ATP loss that may be relatively particular to $\mathrm{SN}$ neurons is the ouabain-sensitive plasma membrane sodium/potassium exchanger, as these currents, which are responsible for maintaining normal resting potential, are exceptionally large in midbrain DA neurons ${ }^{78}$; the ATP-dependent transporter is said to normally use $40 \%$ of the body's
ATP, but the relative level may be even higher in the SN. Another possible site sensitive to ATP loss is the ATPdriven proton pump on synaptic vesicles; inhibition of this pump leads to redistribution of DA to the cytosol in a manner very similar to methamphetamine. ${ }^{79}$ There are of course many other potential sites, including others within the mitochondria, such as aconitase, which is involved in iron and citric acid handling. Blockade of oxidative phosphorylation at any step would necessarily add to overall oxidative stress, as electrons would not be passed normally between the different substrates of this pathway. Perhaps most importantly, DA itself can block complex 1 activity, ${ }^{80}$ although it may be that the depletion of ATP is more directly due to monoamine oxidase conversion of DA to its metabolite DOPAC, which engenders production of hydrogen peroxide. ${ }^{81}$ MPTP, via a combination of these effects, induces a range of oxidative reactions, including nitration reactions via peroxynitrite, which has been found to react with alphasynuclein $^{82}$ and tyrosine hydroxylase. ${ }^{83}$ While the 6-hydroxydopamine (6-OHDA) model, which is selectively neurotoxic for DA neurons, ${ }^{84}$ suggests that the DA uptake transporter and oxyradical products derived from DA metabolism may initiate selective SN degeneration, the role for oxidized cytosolic DA initially came from work with methamphetamine toxicity. ${ }^{85,86}$ This drug redistributes DA from synaptic vesicles, where the trans- 
mitter is held in a reduced state at nearly molar concentrations, to the cytosol, which generally manifests low micromolar concentrations and is a comparatively oxidizing environment. ${ }^{87}$ The resulting oxidized compound, DA-quinone, ${ }^{88-90}$ has been found to react with the DA uptake transporter, ${ }^{91}$ and as above, synuclein, ${ }^{41}$ and is likely involved in reactions with many other sites. It has been suggested that MPP + may similarly act to increase cytosolic DA, in addition to its effects on complex $1 .^{92}$ Native antioxidant supplements, including reduced glutathione, its precursor $\mathrm{N}$-acetylcysteine, vitamin $\mathrm{E}$, tetrahydrobiopterin (which is highly expressed in DA neurons as a cofactor for tyrosine hydroxylase), the enzyme superoxide dismutase, and the monoamine oxidase inhibitor selegiline (monoamine oxidase produces hydrogen peroxide) have all been neuroprotective in experimental PD models, ${ }^{93}$ as are compounds such as S-methylthiocitrulline, ${ }^{94}$ which inhibit nitric oxide synthesis and downstream peroxynitrite formation.

One obvious clue that even normal SN (and locus ceruleus) neurons undergo stress from reactive cytosolic DA (or norepinephrine) is the presence of NM, which is specifically expressed in these neurons. This pigment is composed of DA-quinone, DA-semiquinone, and the lipids and proteins (mostly via reaction with cysteine residues) to which these oxidizing agents have reacted. ${ }^{95}$ NM avidly binds iron and a variety of other metals, which seems to explain the basis for high iron levels in the $\mathrm{SN}$, and has been suggested to act as a pool for transition metals that could contribute to oxyradical formation by the Fenton reaction. ${ }^{96}$ A particular component of NM may be DA-glutathione, as glutathione may provide a first line of defense against cytosolic DA-quinone. NM is located within macroautophagic granules, ${ }^{97}$ which are normally organelles that are destined to translocate organelles and cytoplasm to lysosomes for degradation under conditions of cellular stress. ${ }^{98}$ For both NM granules, and lipofuscin granules containing the aging pigment that is also present in NM granules, the fusion with lysosomes and breakdown is either slowed or halted so that the pigment builds up throughout human lifetime.

Another strong reason to suspect a role for cytosolic DA in PD is that neuroprotection is provided by expression of the synaptic vesicle catecholamine uptake transporter (vesicular monoamine transporter; VMAT2). Indeed, this transporter was originally identified in cell lines selected for resistance to MPP+ toxicity. ${ }^{99}$ Overexpression of the transporter increases DA accumulation in synaptic vesicles, ${ }^{100}$ and so may also reduce the level of DA in the cytosol, although this has not yet been directly demonstrated. DA neurons that underexpress VMAT2 are more susceptible to methamphetamine ${ }^{101,102}$ and MPTP toxicity, ${ }^{103}$ whereas overexpression blocks the biosynthesis of NM. ${ }^{97}$

\section{Protein degradation}

As mentioned above, it is striking that UCHL-1 and parkin are both enzymes that act in the ubiquitin pathway, and DJ-1 participates in the regulation of a similar pathway that adds SUMO peptides to regulate degradation. It has therefore been suggested that PD may result directly from altered protein degradation. ${ }^{104}$ Some more direct evidence for this notion is that parkin up-regulation is protective against some toxic interventions or mutant alpha-synuclein, whereas decreasing parkin activity results in accumulation of potentially toxic proteins. ${ }^{61,62,105,106}$ While attractive, this hypothesis would not by itself explain the selectivity of the disease for the $\mathrm{SN}$, and it appears that additional factors are missing in this puzzle, such as the presence of cytosolic DA. There are at present only preliminary reports on the effects of these proteins on lysosomal protein degradation ${ }^{43,56,107}$ and none on effects on lipid metabolism, although the relationship between different degradative pathways is complex, and an effect on one often leads to compensatory changes in others. ${ }^{108}$

\section{SN neuronal death in comparison to the ventral tegmental area}

A remarkable feature of PD is that while SN DA neurons, particularly in the ventral tier, undergo selective death, the neighboring DA neurons of the ventral tegmental area (VTA) are generally unaffected. The reason for this selective pattern of dopaminergic neuronal death remains unclear. In addition to not exhibiting NM, and thus apparently under less long-term oxidative stress from cytosolic DA, suggestions have been centered on differential expression of a variety of proteins. The calcium binding protein, calbindin, is more highly expressed in the VTA. ${ }^{109}$ VMAT2 expression may also be somewhat higher ${ }^{110}$ (Dwight German, personal communication). Rats, which are resistant to MPTP toxicity, appear to package DA in synaptic vesicles more efficiently than do mice, ${ }^{111}$ which are susceptible to the toxin. SN neurons appear to have a preferential expression of GIRK2, ${ }^{112}$ a potassium channel that is mutated in the weaver mouse, which exhibits specific SN and cerebellar degeneration. The growth factor GDNF plays a greater neuronal rescue role for VTA than SN DA neurons, although this has only been observed for early postnatal neurons. ${ }^{113}$ Whatever the reason for the difference in susceptibility of these neighboring dopaminergic populations, it is likely an important clue for the pathway of PD pathogenesis.

\section{FINAL DEATH PATHWAYS IN PD}

\section{Forms of cell death}

Current dogma states that cell death processes can be divided into apoptotic pathways, which are "pro- 
grammed" forms of cell death that terminate in destruction of DNA chains, and "necrotic" death, which essentially means anything else that kills cells. While these pathways were elucidated to analyze mitotically active cells in cancer and other systems, the pull to apply them to neurodegeneration has been irresistible, in part because it would seem that specific steps in the pathways might be inhibited as a clinical therapy. Much effort has been spent to observe or claim an apoptotic mode of SN death in PD, although the rate of cell death, in which tens of thousands of neurons likely die over a period of decades, would be unobservable by DNA labeling or other approaches which would show ongoing processes that last only for hours. These comments notwithstanding, there is evidence that apoptotic pathways could occur, as PD patients may express up-regulation of proteins expressed in apoptotic pathways such as p53, CD95, and caspases. ${ }^{114}$ It may be that apoptosis in PD is so far downstream from the ultimate neurotoxic insult that the cell would die in a necrotic pathway if denied the postmitotic equivalent of an apoptotic demise.

In contrast to PD itself, there is good evidence for apoptotic pathways in experimental PD models. MPTP activates poly(ADP-ribose) polymerase (PARP) and Bax, enzymes linked to apoptosis, and induces DNA modifications downstream from peroxynitrite synthesis, activation of caspase- 3 , and release of cytochrome C from mitochondria, while up-regulation of anti-apoptotic proteins blocks MPTP-mediated cell death. ${ }^{115}$

\section{Inflammation and gliosis}

An increase of astrocytes and microglia (also known as brain macrophages), known as gliosis, is found around the degenerating SN neurons in PD. It is striking that patients with MPTP-induced parkinsonism continue to show degeneration long after the toxin must have been cleared, and microglial activation could play a role in this ongoing cell death. While glial and microglial cells presumably provide protective functions, by, for example, supplying glial-derived neurotrophic factor (GDNF), interferons, and necrosis factor (TNF), there is a widespread opinion that the microglia in particular may participate in an ongoing cell death following the initial toxic insult. ${ }^{116}$ These cells divide rapidly given an appropriate stress, and produce many potentially noxious compounds, including pro-inflammatory cytokines and prostaglandins, and reactive oxygen and nitrogen species. Activation of microglia may result from exposure to extraneuronal NM following an initial phase of cell death. ${ }^{117}$ Surprisingly, a cyclooxygenase, Cox-2, which acts to produce prostaglandins that may trigger the inflammatory response, looks to be expressed by $\mathrm{SN}$ neurons rather than the surrounding glia, suggesting that the $\mathrm{SN}$ neuron itself could trigger gliosis. ${ }^{118}$

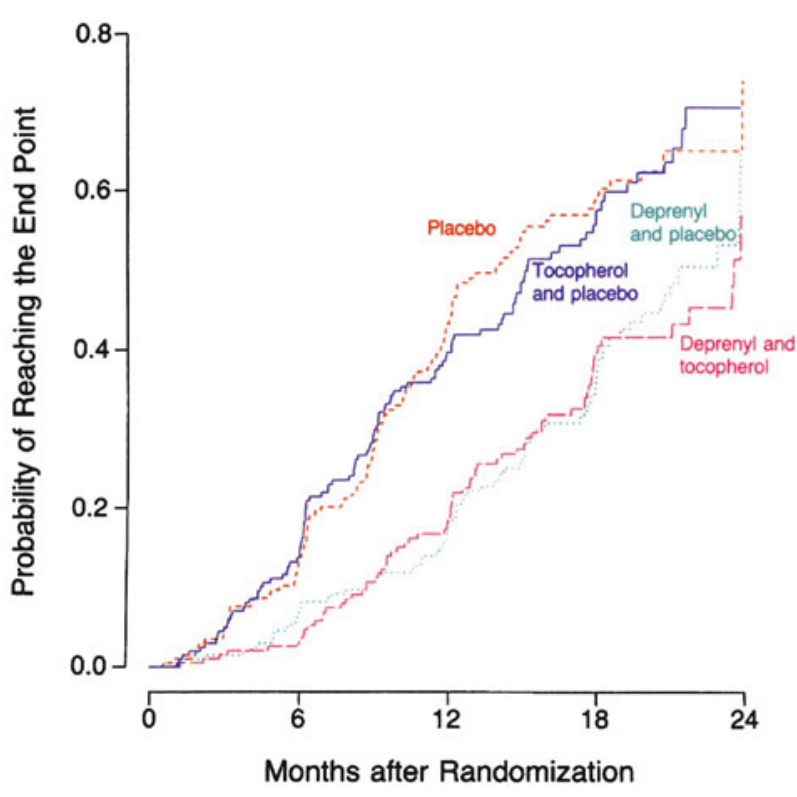

FIG. 5. Kaplan-Meier curves of the cumulative probability of reaching the endpoint (need for dopaminergic therapy) in the DATATOP study. Subjects receiving selegiline (deprenyl) averaged about 9 months longer before requiring dopaminergic therapy compared to placebo and alpha-tocopherol (which had the same outcome as placebo). From The Parkinson Study Group. Effects of tocopherol and deprenyl on the progression of disability in early Parkinson's disease. N Engl J Med 328:176-183, 1993. Copyright (C) 1993, Massachusetts Medical Society. All rights reserved.

\section{NEUROPROTECTIVE STRATEGIES AND CLINICAL TRIALS}

Neuroprotection can be considered a form of therapy to slow the rate of progression of a neurodegenerative disease. Concepts of potential neuroprotective approaches for PD have developed over the last decade. Those that have developed into controlled clinical trials have focused on agents that reduce oxidative stress, combat excitotoxicity, provide trophic factors, enhance mitochondria function, counteract inflammation and inhibit apoptosis. So far, no trials to inhibit protein aggregation, to regulate cytosolic DA levels, or enhance the ubiquitinproteasome system have been undertaken, largely because of lack of reasonable agents to test.

Antioxidative trials. The first controlled clinical trial for the purpose of evaluating medications as neuroprotective agents was the Deprenyl and Tocopherol Antioxidative Therapy of Parkinsonism (DATATOP) study. ${ }^{119}$ Deprenyl (selegiline) is an irreversible MAO-B inhibitor and was known to prevent the conversion of MPTP to MPP+, and thus protect animals from the toxicity of MPTP. As an MAO-B inhibitor, it would reduce the oxidative deamination of DA to DOPAC and hydrogen peroxide, and thus decrease the formation of oxyradicals from hydrogen peroxide. Selegiline was tested along with the antioxidant alpha-tocopherol (vita$\min E$ ), in a $2 \times 2$ design. Patients were enrolled in the 
study early in the course of the illness, and did not require symptomatic therapy. They were placed on selegiline (5 mg b.i.d.), alpha-tocopherol (1,000 IU b.i.d.), the combination, or double placebo, with approximately 200 subjects in each of the four treatment arms. The primary endpoint was the need for dopaminergic therapy. The study showed that tocopherol had no effect in delaying parkinsonian disability, but selegiline delayed symptomatic treatment by 9 months (FIG. 5). ${ }^{120}$ It also reduced the rate of worsening of the Unified Parkinson Disease Rating Scale (UPDRS) by half (Table 2). Other investigators conducted other studies testing selegiline, showing similar results. ${ }^{121,122}$

Because the DATATOP study found that selegiline has a mild symptomatic effect that is long lasting, one could explain its ability to delay progression of disability entirely on this symptomatic effect. Furthermore, selegiline's benefit in delaying the introduction of levodopa gradually diminishes over time ${ }^{120}$ with the best results occurring in the first year of treatment. The odds ratio (the need for the introduction of levodopa for selegilinetreated patients divided by control patients) increased from 0.35 for the first 6 months, to 0.38 in the second 6 months, to 0.77 in the third 6 months, and to 0.86 after 18 months. Thus, uncertainty prevailed as to whether selegiline's ability to delay the need for symptomatic therapy was entirely due to its mild symptomatic effect or if there was any protective effect as well. Selegiline treatment also provided a statistically significantly decreased risk for developing freezing of gait. ${ }^{123}$ Again, it cannot be discerned whether this benefit was because of selegiline's mild symptomatic benefit or of some unknown neuroprotective effect.

While the subjects in DATATOP were being followed in open-label evaluations, and eventually all received selegiline and levodopa, 368 of them agreed to be rerandomized to either selegiline or placebo, while remaining on levodopa (the BLIND-DATE Study). They were studied in a double-blind design for 21 months and evaluated for the progression of clinical PD. The subjects assigned to selegiline required a lower dosage of levodopa, had a slower rate of worsening of symptoms and signs of PD (Table 3) and had less freezing of gait than
TABLE 2. Average Annual Rate of Decline in UPDRS Scores in the DATATOP Study.

\begin{tabular}{lc}
\hline Treatment & Total UPDRS \\
\hline Placebo & $14.02 \pm 12.32$ \\
Tocopherol & $15.16 \pm 16.12$ \\
Selegiline & $7.00 \pm 10.76$ \\
Tocopherol and selegiline & $7.28 \pm 11.11$ \\
$p$ Value between the selegiline groups & $<0.001$ \\
$\quad$ and the placebo/tocopherol groups &
\end{tabular}

Results are expressed as mean \pm SD. From Parkinson Study Group, 1993.119

those assigned to placebo. ${ }^{124}$ These results support the view that selegiline does provide some neuroprotective effect. The possibility that this benefit is derived from an anti-apoptotic effect rather than its antioxidative effect is discussed below.

\section{Combating excitotoxicity}

Glutamate is the major excitatory neurotransmitter in the CNS and can induce excitotoxicity. A slow excitotoxic process has been proposed by $\mathrm{Beal}^{125}$ to be a possible mechanism of cell death in PD. Riluzole impairs glutamatergic neurotransmission by blocking voltage-dependent sodium channel currents. In experimental animal models of PD, riluzole was found to have neuroprotective effects. ${ }^{126-129}$ However, in controlled clinical trials in patients with early PD, riluzole was not found to be effective as a neuroprotective agent. ${ }^{130,131}$

\section{Providing trophic factors}

Glial-derived neurotrophic factor (GDNF) promotes the survival of DA neurons, ${ }^{113}$ DA neuron neurite outgrowth, and quantal size (the amount of DA released per synaptic vesicle exocytic event). ${ }^{132}$ When injected into the midbrain of primates rendered parkinsonian by MPTP, there was improvement of the parkinsonian features. ${ }^{133}$ Moreover, DA concentration in the SN was increased on the injected side and the nigral DA neurons were $20 \%$ larger with an increased fiber density. In a subsequent study, primates received infusions of GDNF into a lateral ventricle. ${ }^{134}$ This approach also showed restoration of the nigrostriatal dopaminergic system and

TABLE 3. Change in Total UPDRS after Second Randomization to Either Selegiline or Placebo While Taking Levodopa

\begin{tabular}{lccc}
\hline Duration after Randomization & Placebo & Selegiline & Difference \\
\hline 1 month & $0.50 \pm 7.73$ & $-1.52 \pm 7.54$ & 2.02 \\
3 months & $1.57 \pm 9.41$ & $-0.85 \pm 9.42$ & 2.42 \\
9 months & $4.18 \pm 10.12$ & $1.63 \pm 10.61$ & 2.55 \\
15 months & $5.63 \pm 10.73$ & $0.46 \pm 10.88$ & 5.17 \\
21 months & $7.06 \pm 12.70$ & $1.51 \pm 10.36$ & $p=0.0002$ \\
Increase of L-dopa mg/day & $181 \pm 246$ & $106 \pm 205$ & $p=0.003$ \\
\hline
\end{tabular}

From Shoulson et al. ${ }^{123}$ Higher UPDRS represents more severe PD. 

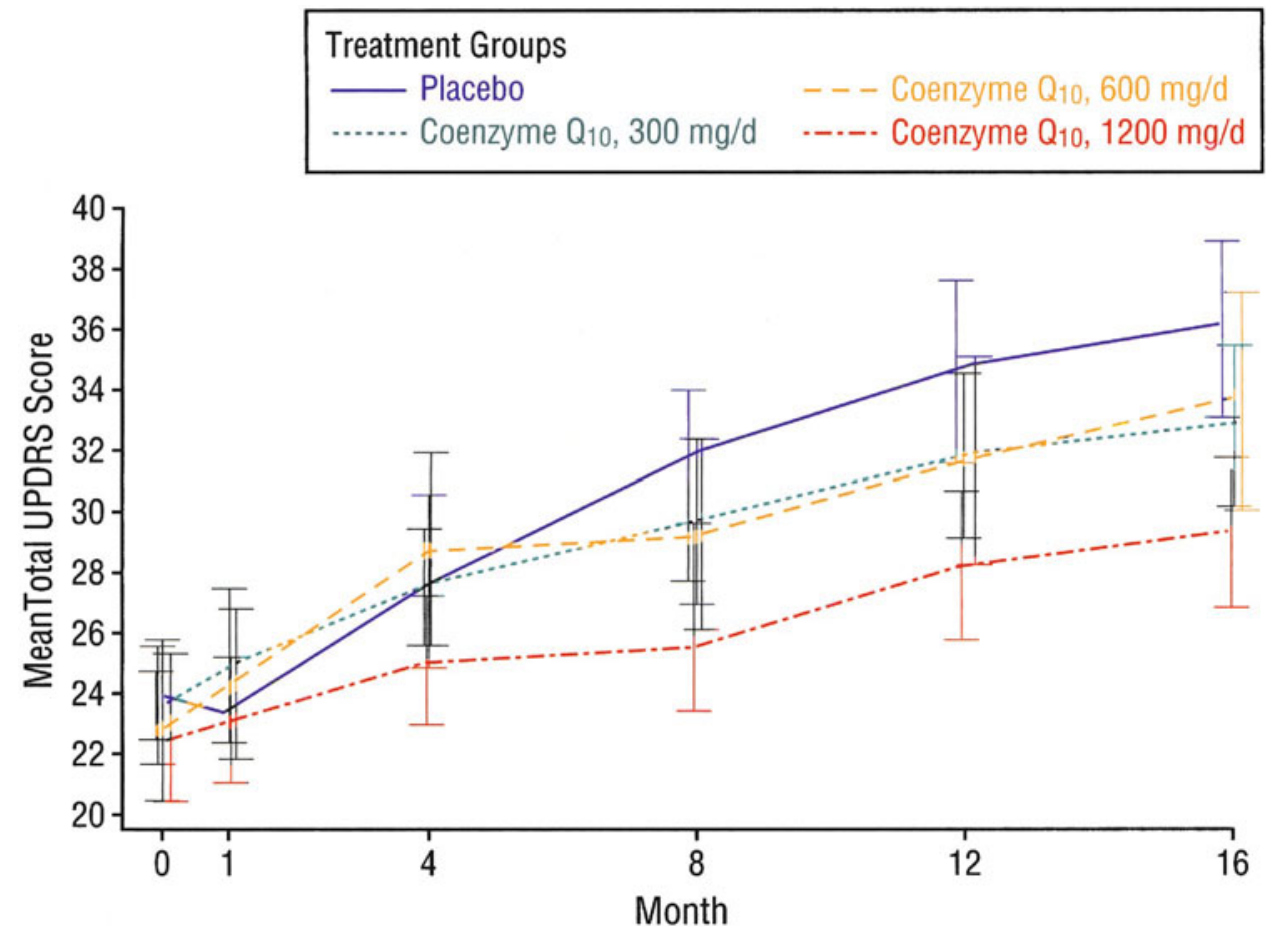

FIG. 6. Change in total UPDRS with different dosages of coenzyme $Q_{10}$. From Shults et al., Effects of Coenzyme $Q_{10}$ in early Parkinson disease-evidence slowing the functional decline. Arch Neurol 59:1541-1550. Copyrighted (C) 2002, American Medical Association. All rights reserved.

improved the motor function in the rhesus monkeys. The functional improvements were associated with pronounced up-regulation and regeneration of nigral DA neurons and their processes innervating the striatum. However, in a randomized, double-blind, placebo-controlled trial of infusing GDNF into the lateral ventricle of patients with PD, there was no clinical improvement. ${ }^{135}$ Nausea, anorexia, and vomiting were common hours to several days after injections of GDNF. Weight loss occurred in the majority of subjects receiving $75 \mathrm{~m} \mu \mathrm{g}$ or larger doses. Paresthesias, often described as electric shocks (Lhermitte sign), were common in GDNF-treated subjects.

One recent promising study, however, showed that infusing GDNF directly into the putamen improved motor performance in patients with PD, and that there was increased FDOPA uptake in some of the patients. ${ }^{136}$ This was an open-label study, but the results were encouraging enough that a controlled clinical trial is now underway.

Another approach of delivering GDNF directly into the brain was successfully achieved in primates using lentoviral vectors containing the gene for producing GDNF. ${ }^{137}$ Lenti-GDNF was injected into the striatum and $\mathrm{SN}$ of rhesus monkeys treated 1 week prior with MPTP. Lenti-GDNF reversed functional deficits and completely prevented nigrostriatal degeneration. Longterm gene expression (8 months) was seen in intact monkeys given this treatment.

A novel nonimmunosuppressive immunophilin ligand,
GPI-1,046, (henceforth called neuroimmunophilin) was found to have trophic activity, including regenerative sprouting from spared nigrostriatal dopaminergic neurons following MPTP toxicity in mice or 6-OHDA toxicity in rats. ${ }^{138}$ Since then, there have been reports supporting a regenerative effect by neuroimmunophilins ${ }^{139}$ and with a proposed mechanism of increasing glutathione in brain. ${ }^{140,141}$ On the other hand, there have been many reports that failed to find such benefits in various animal models of PD, including primates. ${ }^{142-145}$ One controlled clinical trial testing neuroimmunophilin in patients was unsuccessful, but a larger one is now underway.

\section{Enhancing mitochondria and energy function}

Coenzyme $\mathrm{Q}_{10}$ is the electron acceptor for mitochondrial complexes I and II and also a potent antioxidant. Complex I activity was found to be affected by MPTP, and subsequently found to be selectively decreased postmortem in $\mathrm{SN}$ in patients with PD. ${ }^{146}$ Coenzyme $\mathrm{Q}_{10}$ is reduced in the mitochondria ${ }^{147}$ and in sera of patients with PD. ${ }^{148}$ Oral supplementation of coenzyme $\mathrm{Q}_{10}$ in rats resulted in increases of coenzyme $Q_{10}$ in cerebral cortex mitochondria. ${ }^{149}$ A controlled clinical pilot trial of coenzyme $\mathrm{Q}_{10}$ was undertaken in 80 patients with early PD. They were randomized into four equal arms and assigned $300 \mathrm{mg} /$ day, $600 \mathrm{mg} /$ day, 1,200 mg/day or placebo and followed up to 16 months. ${ }^{150}$ There was a positive trend $(p=0.09)$ for a linear relationship between the dosage and the mean change in the total UPDRS score. The 


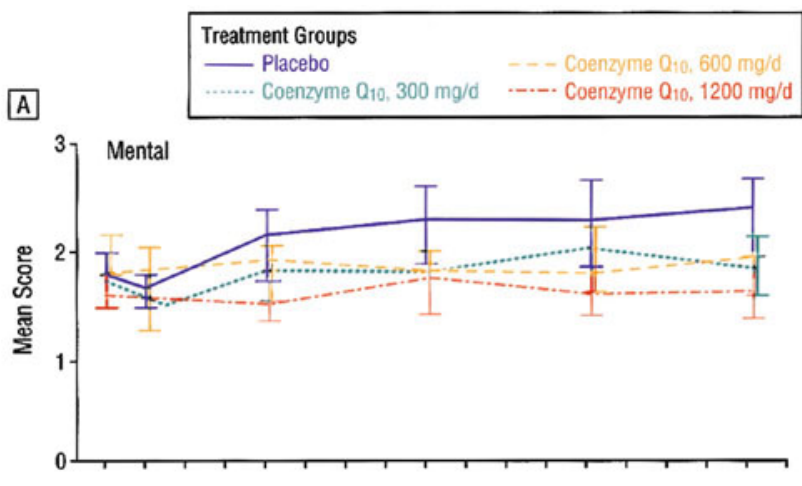

B

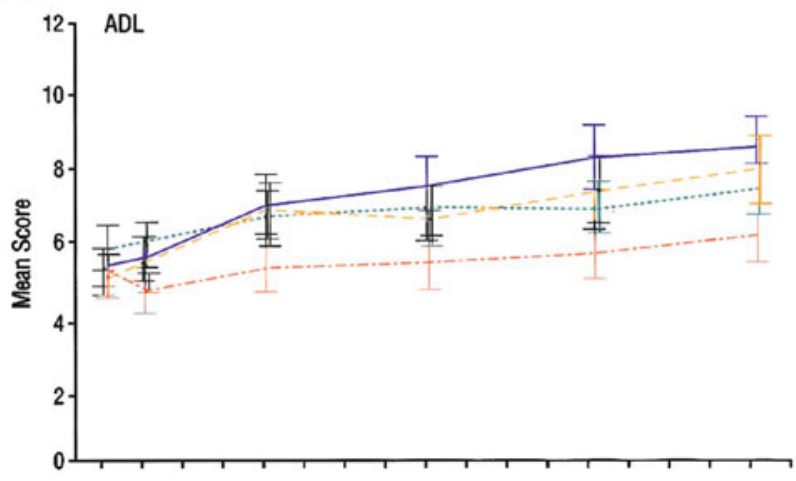

C

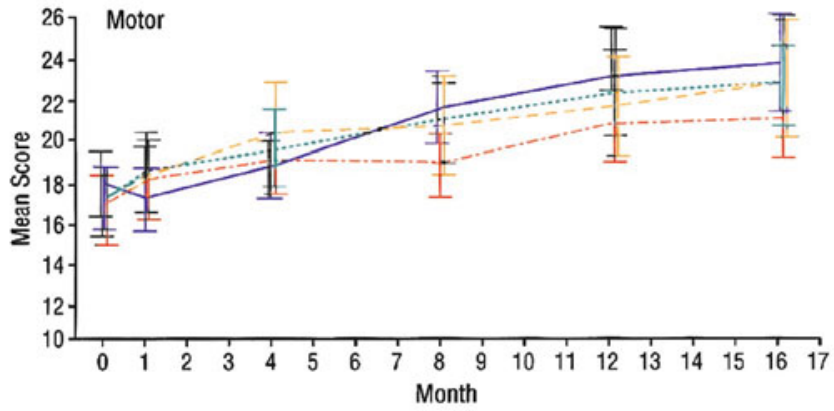

FIG. 7. Change in the different components of the UPDRS with coenzyme $Q_{10}$. From Shults et al., Effects of coenzyme $Q_{10}$ in early Parkinson disease-evidence of slowing of the functional decline. Arch Neurol 59:1541-1550. Copyrighted (C) 2002, American Medical Association. All rights reserved.

highest dose group (total UPDRS change of +6.69 ) was statistically less than the UPDRS change of +11.99 for the placebo group (FIG. 6). The change in UPDRS for the lower doses showed no significant difference from the placebo group. There was a slower decline in the change of all three components of the UPDRS scores in the $1,200 \mathrm{mg} /$ day group, with the greatest effect in part II [the subjective Activities of Daily Living (ADL) component] (FIG. 7). This raises the question of whether patients on $1,200 \mathrm{mg} /$ day of coenzyme $\mathrm{Q}_{10}$ might simply feel better rather than having an objective improvement of their motoric features of PD. After one month of treatment, there was improvement of the Part II UPDRS (ADL) score in the $1,200 \mathrm{mg} / \mathrm{d}$ group of -0.66 , compared to worsening in the placebo group of +0.52 . This wash-in effect supports the concern that there might be a "feel good" response from coenzyme $\mathrm{Q}_{10}$ rather than a neuroprotective effect. Also, it should be noted that those treated with the $1,200 \mathrm{mg} / \mathrm{d}$ failed to show a delay in the need for dopaminergic therapy. Of course, the study was not powered for a modest effect, and the study investigators urged caution in interpretation of the results until a larger study could be conducted and evaluated.

Creatine is a guanidine-derived compound generated in the body. The creatine/phosphocreatine system functions as an energy buffer between the cytosol and mito- chondria. ${ }^{151}$ Creatine has been proposed to serve as a neuroprotectant in neurodegeneration, and it is now being tested in a controlled clinical trial in early PD.

\section{Counteracting inflammation}

As mentioned above, gliosis and reactive microglia are seen in the SN of patients with PD, indicating an ongoing inflammatory process. Such changes have also been seen following MPTP ${ }^{116}$ and rotenone ${ }^{152}$ neurotoxicity. Inflammation is considered to be a secondary effect, but may play an important role in enhancing neurodegeneration by the production of cytokines and prostaglandins. Experimental animal models have shown that treatment with the antibiotic minocycline, can reduce the level of degeneration by MPTP. ${ }^{152,153}$ As a result of these reports, a controlled clinical trial testing minocycline is planned.

\section{Inhibiting apoptosis}

Studies on selegiline, in an effort to explain its effectiveness in the DATATOP study, have shown it to have a neuronal rescue effect independent of its MAO inhibition. ${ }^{154}$ Ultimately this finding led to the investigation of other agents for their neurorescue effect, resulting in the discovery that propargylamines have an anti-apoptotic action, leading to at least one, a glyceraldehydes-3-phosphate dehydrogenase stabilizer, which is currently being 
tested in a controlled clinical trial. ${ }^{155}$ Selegiline is a propargylamine drug, as is another drug in development, rasagiline. Another anti-apoptotic drug, CEP1347, is also being tested in a large controlled clinical trial. This drug inhibits mitogen linear kinases and has been an effective neuroprotectant in animal models of PD.

\section{SUMMARY}

The efforts to understand the precise pathway by which neurodegenerative processes proceed and the development of approaches to modulate them offers the promise to eventually enable the prevention of these diseases. So far, no medication or surgical approach has been accepted as having been proven to be neuroprotective in PD. But with so much new knowledge on pathogenesis and genetic mechanisms having been presented in the last few years, there are now new ideas on drugs that could be tested in clinical trials. As mentioned above, some of these trials are already underway. Others are in the planning stages, and still others are only being contemplated. One problem is whether there are enough early stage patients available to be enrolled into the proposed trials. Are there enough financial resources available? It would be best to have a priority of agents to be tested based on the most likely to be successful. Fortunately, the National Institute of Neurological Diseases and Stroke (NINDS) has already established an Oversight Committee to guide the Institute in this type of strategy. Enthusiasm is high; let the studies begin!

\section{REFERENCES}

1. Fahn S, Przedborski S. Parkinsonism. In: Merritt's neurology (Rowland LP, ed), pp 679-693. Philadelphia: Lippincott Williams \& Wilkins, 2000.

2. Fahn S. Description of Parkinson's disease as a clinical syndrome. Ann NY Acad Sci 991:1-14, 2003.

3. Seibyl JP, Marek KL, Quinlan D, Sheff K, Zoghbi S, Zea-Ponce $\mathrm{Y}$ et al. Decreased single-photon emission computed tomographic [123I]beta-CIT striatal uptake correlates with symptom severity in Parkinson's disease. Ann Neurol 38:589-598, 1995.

4. Eidelberg D, Moeller JR, Ishikawa T, Dhawan V, Spetsieris P, Chaly $\mathrm{T}$ et al. Assessment of disease severity in parkinsonism with fluorine-18-fluorodeoxyglucose and PET. J Nucl Med 36: 378-383, 1995.

5. Snow BJ, Lee CS, Schulzer M, Mak E, Calne DB. Longitudinal fluorodopa positron emission tomographic studies of the evolution of idiopathic Parkinsonism. Ann Neurol 36:759-764, 1994.

6. Morrish PK, Sawle GV, Brooks DJ. An [F-18]dopa-PET and clinical study of the rate of progression in Parkinson's disease. Brain 119:585-591, 1996.

7. Benamer HT, Patterson J, Wyper DJ, Hadley DM, Macphee GJ, Grosset DG. Correlation of Parkinson's disease severity and duration with 123I-FP-CIT SPECT striatal uptake. Mov Disord 15: 692-698, 2000.

8. Mayeux R, Marder K, Cote LJ, Denaro J, Hemenegildo N, Mejia $\mathrm{H}$ et al. The frequency of idiopathic Parkinson's disease by age, ethnic group, and sex in northern Manhattan, 1988-1993. Am J Epidemiol 142:820-827, 1995.

9. de Rijk MC, Tzourio C, Breteler MM, Dartigues JF, Amaducci L, Lopez-Pousa S et al. Prevalence of parkinsonism and Parkinson's disease in Europe: the EUROPARKINSON Collaborative Study.
European Community Concerted Action on the Epidemiology of Parkinson's disease. J Neurol Neurosurg Psychiatry 62:10-15, 1997.

10. Bower JH, Maraganore DM, McDonnell SK, Rocca WA. Influence of strict, intermediate, and broad diagnostic criteria on the age- and sex-specific incidence of Parkinson's disease. Mov Disord 15:819-825, 2000 .

11. Twelves D, Perkins KS, Counsell C. Systematic review of incidence studies of Parkinson's disease. Mov Disord 18:19-31, 2003.

12. Baldereschi M, Di Carlo A, Rocca WA, Vanni P, Maggi S, Perissinotto E et al. Parkinson's disease and parkinsonism in a longitudinal study: two-fold higher incidence in men. ILSA Working Group. Italian Longitudinal Study on Aging. Neurology 55:1358-1363, 2000.

13. Diederich NJ, Moore CG, Leurgans SE, Chmura TA, Goetz CG. Parkinson disease with old-age onset: a comparative study with subjects with middle-age onset. Arch Neurol 60:529-533, 2003.

14. Kish SJ, Shannak K, Rajput A, Deck JH, Hornykiewicz O. Aging produces a specific pattern of striatal dopamine loss: implications for the etiology of idiopathic Parkinson's disease. J Neurochem 58:642-648, 1992.

15. Scherman D, Desnos C, Darchen F, Pollak P, Javoy-Agid F, Agid Y. Striatal dopamine deficiency in Parkinson's disease: role of aging. Ann Neurol 26:551-557, 1989.

16. Booij J, Bergmans P, Winogrodzka A, Speelman JD, Wolters EC. Imaging of dopamine transporters with [123I]FP-CIT SPECT does not suggest a significant effect of age on the symptomatic threshold of disease in Parkinson's disease. Synapse 39:101-108, 2001.

17. Kubis N, Faucheux BA, Ransmayr G, Damier P, Duyckaerts C, Henin D et al. Preservation of midbrain catecholaminergic neurons in very old human subjects. Brain 123:366-373, 2000.

18. Fearnley JM, Lees AJ. Ageing and Parkinson's disease: substantia nigra regional selectivity. Brain 114:2283-2301, 1991.

19. Zeiring A, Berger L, Heineman S, Lee J. Piperidine derivatives. Part III. 4-arylpiperidines. J Org Chem 12:894-903, 1947.

20. Schmidle CJ, Mansfield RC. The aminomethylation of olefins. IV. The formation of 1-alkyl-4-aryl-1.2.3.6-tetrahydropyridines. Am J Chem 78:425-428, 1955.

21. Davis GC, Williams AC, Markey SP, Ebert MH, Caine ED, Reichert CM et al. Chronic Parkinsonism secondary to intravenous injection of meperidine analogues. Psychiatry Res 1:249254, 1979.

22. Wright JM, Wall RA, Perry TL, Paty DW. Chronic parkinsonism secondary to intranasal administration of a product of meperidineanalogue synthesis. $N$ Engl J Med 310:325, 1984.

23. Langston JW, Ballard PA. Parkinson's disease in a chemist working with 1-methyl-4-phenyl-1,2,5,6-tetrahydropyridine. $N$ Engl $J$ Med 309:310, 1983.

24. Langston JW, Ballard P, Tetrud JW, Irwin I. Chronic Parkinsonism in humans due to a product of meperidine-analog synthesis. Science 219:979-980, 1983.

25. Langston JW, Palfreman J. The case of the frozen addicts. New York: Pantheon Books, 1995.

26. Burns RS, Chiueh CC, Markey SP, Ebert MH, Jacobowitz DM, Kopin IJ. A primate model of parkinsonism: selective destruction of dopaminergic neurons in the pars compacta of the substantia nigra by N-methl-4-phenyl-1,2,36-tetrahydropyridine. Proc Natl Acad Sci USA, 80:4546-4550, 1983.

27. Widner H, Tetrud J, Rehncrona S, Snow B, Brundin P, Gustavii $\mathrm{B}$ et al. Bilateral fetal mesencephalic grafting in two patients with parkinsonism induced by 1-methyl-4-phenyl-1,2,3,6-tetrahydropyridine (MPTP). N Engl J Med 327:1556-1563, 1992.

28. Mena I, Court J, Fuenzalida S, Papavasiliou PS, Cotzias GC. Modification of chronic manganese poisoning. Treatment with L-dopa or 5-OH tryptophane. N Engl J Med 282:5-10, 1970.

29. Cook DG, Fahn S, Brait KA. Chronic manganese intoxication. Arch Neurol 30:59-64, 1974.

30. Huang CC, Chu NS, Lu CS, Wang JD, Tsai JL, Tzeng JL et al. Chronic manganese intoxication. Arch Neurol 46:1104-1106, 1989.

31. Tanner CM. Epidemiology of Parkinson's disease. Neurol Clin 10:317-329, 1992. 
32. Betarbet R, Sherer TB, MacKenzie G, Garcia-Osuna M, Panov AV, Greenamyre JT. Chronic systemic pesticide exposure reproduces features of Parkinson's disease. Nat Neurosci 3:1301-1306, 2000

33. Hernan MA, Takkouche B, Caamano-Isorna F, Gestal-Otero JJ. A meta-analysis of coffee drinking, cigarette smoking, and the risk of Parkinson's disease. Ann Neurol 52:276-284, 2002.

34. Tanner CM, Ottman R, Goldman SM, Ellenberg J, Chan P, Mayeux $\mathrm{R}$ et al. Parkinson disease in twins: an etiologic study. JAMA 281:341-366, 1999.

35. Polymeropoulos MH, Lavedan C, Leroy E, Ide SE, Dehejia A, Dutra A et al. Mutation in the alpha-synuclein gene identified in families with Parkinson's disease. Science 276:2045-2047, 1997.

36. Kruger R, Kuhn W, Muller T, Woitalla D, Graeber M, Kosel S et al. Ala30Pro mutation in the gene encoding alpha-synuclein in Parkinson's disease. Nat Genet 18:106-108, 1998.

37. Spillantini MG, Schmidt ML, Lee VMY, Trojanowski JQ, Jakes R, Goedert M. Alpha-synuclein in Lewy bodies. Nature 388:839840, 1997.

38. Ueda K, Fukushima H, Masliah E, Xia Y, Iwai A, Yoshimoto M et al. Molecular cloning of cDNA encoding an unrecognized component of amyloid in Alzheimer disease. Proc Natl Acad Sci USA 90:11282-11286, 1993.

39. Engelender S, Kaminsky Z, Guo X, Sharp AH, Amaravi RK, Kleiderlein JJ et al. Synphilin-1 associates with alpha-synuclein and promotes the formation of cytosolic inclusions. Nat Genet 22:110-114, 1999.

40. Uversky VN, Li J, Bower K, Fink AL. Synergistic effects of pesticides and metals on the fibrillation of alpha-synuclein: implications for Parkinson's disease. Neurotoxicology 23:527-536, 2002.

41. Conway KA, Rochet JC, Bieganski RM, Lansbury PT Jr. Kinetic stabilization of the alpha-synuclein protofibril by a dopaminealpha-synuclein adduct. Science 294:1346-1349, 2001.

42. Yamin G, Glaser CB, Uversky VN, Fink AL. Certain metals trigger fibrillation of methionine-oxidized alpha-synuclein. $J$ Biol Chem 16:16, 2003.

43. Paxinou E, Chen Q, Weisse M, Giasson BI, Norris EH, Rueter $\mathrm{SM}$ et al. Induction of alpha-synuclein aggregation by intracellular nitrative insult. J Neurosci 21:8053-8061, 2001.

44. Cole NB, Murphy DD. The cell biology of alpha-synuclein: a sticky problem? Neuromolecular Med 1:95-109, 2002.

45. Clayton DF, George JM. The synucleins: a family of proteins involved in synaptic function, plasticity, neurodegeneration and disease. Trends Neurosci 21:249-254, 1998.

46. Maroteaux L, Campanelli JT, Scheller RH. Synuclein: a neuronspecific protein localized to the nucleus and presynaptic nerve terminal. J Neurosci 8:2804-2815, 1988.

47. Abeliovich A, Schmitz Y, Farinas I, Choi-Lundberg D, Ho WH, Verdugo JMG et al. Mice lacking alpha-synuclein display functional deficits in the nigrostriatal dopamine system. Neuron 25 : 239-252, 2000.

48. Cabin DE, Shimazu K, Murphy D, Cole NB, Gottschalk W, McIlwain KL et al. Synaptic vesicle depletion correlates with attenuated synaptic responses to prolonged repetitive stimulation in mice lacking alpha-synuclein. J Neurosci 22:8797-8807, 2002.

49. Murphy DD, Rueter SM, Trojanowski JQ, Lee VM. Synucleins are developmentally expressed, and alpha-synuclein regulates the size of the presynaptic vesicular pool in primary hippocampal neurons. J Neurosci 20:3214-3220, 2000.

50. Perez RG, Waymire JC, Lin E, Liu JJ, Guo F, Zigmond MJ. A role for alpha-synuclein in the regulation of dopamine biosynthesis. J Neurosci 22:3090-3099, 2002.

51. Lee FJ, Liu F, Pristupa ZB, Niznik HB. Direct binding and functional coupling of alpha-synuclein to the dopamine transporters accelerate dopamine-induced apoptosis. FASEB J, 15:916926, 2001.

52. Singleton A, Farrer M, Johnson J, Singleton A, Hague S, Kachergus J, Hulihan $\mathrm{M}$ et al. Alpha-synuclein locus triplication in PD. Science 302:841, 2003.

53. Dauer W, Kholodilov N, Vila M, Trillat AC, Goodchild R, Larsen $\mathrm{KE}$ et al. Resistance of alpha -synuclein null mice to the parkin- sonian neurotoxin MPTP. Proc Natl Acad Sci USA 99:1452414529, 2002.

54. Lotharius J, Barg S, Wiekop P, Lundberg C, Raymon HK, Brundin P. Effect of mutant alpha-synuclein on dopamine homeostasis in a new human mesencephalic cell line. J Biol Chem 277:38884-38894, 2002.

55. Shimura H, Schlossmacher MG, Hattori N, Frosch MP, Trockenbacher A, Schneider R et al. Ubiquitination of a new form of alpha-synuclein by parkin from human brain: implications for Parkinson's disease. Science 293:263-269, 2001.

56. Webb JL, Ravikumar B, Atkins J, Skepper JN, Rubinsztein DC Alpha-synuclein is degraded by both autophagy and the proteasome. J Biol Chem 28:25009-25013, 2003.

57. Kitada T, Asakawa S, Hattori N, Matsumine H, Yamamura Y, Minoshima $S$ et al. Mutations in the parkin gene cause autosomal recessive juvenile parkinsonism. Nature 392:605-608, 1998.

58. Lucking CB, Durr A, Bonifati V, Vaughan J, De Michele G, Gasser T et al. Association between early-onset Parkinson's disease and mutations in the parkin gene. N Engl J Med 342:15601567, 2000.

59. Farrer M, Chan P, Chen R, Tan L, Lincoln S, Hernandez D et al. Lewy bodies and parkinsonism in families with parkin mutations. Ann Neurol 50:293-300, 2001.

60. Foroud T, Uniacke SK, Liu L, Pankratz N, Rudolph A, Halter C et al. Heterozygosity for a mutation in the parkin gene leads to later onset Parkinson disease. Neurology 60:796-801, 2003.

61. Zhang Y, Gao J, Chung KK, Huang H, Dawson VL, Dawson TM. Parkin functions as an E2-dependent ubiquitin- protein ligase and promotes the degradation of the synaptic vesicle-associated protein, CDCrel-1. Proc Natl Acad Sci USA 97:13354-13359, 2000.

62. Staropoli JF, McDermott C, Martinat C, Schulman B, Demireva $\mathrm{E}$, Abeliovich A. Parkin is a component of an SCF-like ubiquitin ligase complex and protects postmitotic neurons from kainate excitotoxicity. Neuron 37:735-749, 2003.

63. Petrucelli L, O’Farrell C, Lockhart PJ, Baptista M, Kehoe K, Vink L et al. Parkin protects against the toxicity associated with mutant alpha-synuclein. Neuron 36:1007-1019, 2002.

64. Leroy E, Boyer R, Auburger G, Leube B, Ulm G, Mezey E et al. The ubiquitin pathway in Parkinson's disease. Nature 395:451452, 1998.

65. Bonifati V, Rizzu P, van Baren MJ, Schaap O, Breedveld GJ, Krieger E et al. Mutations in the DJ-1 gene associated with autosomal recessive early-onset parkinsonism. Science 299:256259, 2003.

66. Su HL, Li SS. Molecular features of human ubiquitin-like SUMO genes and their encoded proteins. Gene 296:65-73, 2002.

67. Takahashi K, Taira T, Niki T, Seino C, Iguchi-Ariga SM, Ariga $\mathrm{H}$. DJ-1 positively regulates the androgen receptor by impairing the binding of PIASx alpha to the receptor. J Biol Chem 276: 37556-37563, 2001.

68. Mitsumoto A, Nakagawa Y, Takeuchi A, Okawa K, Iwamatsu A, Takanezawa Y. Oxidized forms of peroxiredoxins and DJ-1 on two-dimensional gels increased in response to sublethal levels of paraquat. Free Radic Res 35:301-310, 2001.

69. Johnston JA, Ward CL, Kopito RR. Aggresomes: a cellular response to misfolded proteins. J Cell Biol 143:1883-1898, 1998.

70. Lee HJ, Lee SJ. Characterization of cytoplasmic alpha-synuclein aggregates. Fibril formation is tightly linked to the inclusionforming process in cells. J Biol Chem 277:48976-48983, 2002.

71. Junn E, Lee SS, Suhr UT, Mouradian MM. Parkin accumulation in aggresomes due to proteasome impairment. J Biol Chem 277: 47870-47877, 2002.

72. Volles MJ, Lee SJ, Rochet JC, Shtilerman MD, Ding TT, Kessler JC et al. Vesicle permeabilization by protofibrillar alphasynuclein: implications for the pathogenesis and treatment of Parkinson's disease. Biochemistry 40:7812-7819, 2001.

73. Javitch JA, Snyder SH. Uptake of MPP $(+)$ by dopamine neurons explains selectivity of parkinsonism-inducing neurotoxin, MPTP. Eur J Pharmacol 106:455-456, 1984.

74. Gainetdinov RR, Fumagalli F, Caron MG. Dopamine transporter is required for in vivo MPTP neurotoxicity: evidence from mice lacking the transporter. J Neurochem 69:1322-1325, 1997. 
75. Fumagalli F, Gainetdinov RR, Valenzano KJ, Caron MG. Role of dopamine transporter in methamphetamine-induced neurotoxicity: evidence from mice lacking the transporter. $J$ Neurosci 18: 4861-4869, 1998.

76. Ramsay RR, Salach JI, Singer TP. Uptake of the neurotoxin 1-methyl-4-phenylpyridine (MPP+) by mitochondria and its relation to the inhibition of the mitochondrial oxidation of NAD+linked substrates by MPP + . Biochem Biophys Res Commun 134: 743-748, 1986.

77. Nicklas WJ, Youngster SK, Kindt MV, Heikkila RE. MPTP, MPP+ and mitochondrial function. Life Sci 40:721-729, 1987.

78. Seutin V, Shen KZ, North RA, Johnson SW. Sulfonylurea-sensitive potassium current evoked by sodium-loading in rat midbrain dopamine neurons. Neuroscience 71:709-719, 1996.

79. Pothos EN, Mosharov E, Liu KP, Setlik W, Baldini G, Gershon $\mathrm{MD}$ et al. Stimulation-dependent regulation of secretory vesicle $\mathrm{pH}$, volume, and quantal size. J Physiol (Lond) 542:453-476, 2002.

80. Przedborski S, Jackson-Lewis V, Muthane U, Jiang H, Ferreira M, Naini A-B, Fahn S. Chronic levodopa administration alters cerebral mitochondrial respiratory chain activity. Ann Neurol 34: 715-723, 1993.

81. Gluck M, Ehrhart J, Jayatilleke E, Zeevalk GD. Inhibition of brain mitochondrial respiration by dopamine: involvement of $\mathrm{H}(2) \mathrm{O}(2)$ and hydroxyl radicals but not glutathione-proteinmixed disulfides. $J$ Neurochem 82:66-74, 2002.

82. Przedborski S, Chen Q, Vila M, Giasson BI, Djaldatti R, Vukosavic $\mathrm{S}$ et al. Oxidative post-translational modifications of alphasynuclein in the 1-methyl-4-phenyl-1,2,3,6-tetrahydropyridine (MPTP) mouse model of Parkinson's disease. J Neurochem 76: 637-640, 2001.

83. Blanchard-Fillion B, Souza JM, Friel T, Jiang GC, Vrana K, Sharov $\mathrm{V}$ et al. Nitration and inactivation of tyrosine hydroxylase by peroxynitrite. J Biol Chem 276:46017-46023, 2001.

84. Miller FE, Heffner TG, Kotake C, Seiden LS. Magnitude and duration of hyperactivity following neonatal 6-hydroxydopamine is related to the extent of brain dopamine depletion. Brain Res 229:123-132, 1981

85. Cubells JF, Rayport S, Rajendran G, Sulzer D. Methamphetamine neurotoxicity involves vacuolation of endocytic organelles and dopamine-dependent intracellular oxidative stress. J Neurosci 14: 2260-2271, 1994.

86. Giovanni A, Liang LP, Hastings TG, Zigmond MJ. Estimating hydroxyl radical content in rat brain using systemic and intraventricular salicylate: impact of methamphetamine. J Neurochem 64:1819-1825, 1995.

87. Sulzer D, Rayport S. Amphetamine and other psychostimulants reduce $\mathrm{pH}$ gradients in midbrain dopaminergic neurons and chromaffin granules: a mechanism of action. Neuron 5:797-808, 1990.

88. Hastings TG, Berman SB. Dopamine-induced toxicity and quinone modification of proteins: implications for Parkinson's disease. In: Role of catechol quinone species in cellular toxicity (Creveling CR, ed), pp 69-89. Johnson City, TN: F. P. Graham, 1999.

89. Sulzer D, Zecca L. Intraneuronal dopamine-quinone synthesis: a review. Neurotoxicity Res 1:181-195, 2000.

90. Graham DG. Oxidative pathways for catecholamines in the genesis of neuromelanin and cytotoxic quinones. Mol Pharmacol 14:633-643, 1978.

91. Whitehead RE, Ferrer JV, Javitch JA, Justice JB. Reaction of oxidized dopamine with endogenous cysteine residues in the human dopamine transporter. J Neurochem 76:1242-1251, 2001.

92. Lotharius J, O'Malley KL. The parkinsonism-inducing drug 1-methyl-4-phenylpyridinium (MPP+) triggers intracellular dopamine oxidation: a novel mechanism of toxicity. $J$ Biol Chem 275:38581-38588, 2000.

93. Davidson C, Gow AJ, Lee TH, Ellinwood EH. Methamphetamine neurotoxicity: necrotic and apoptotic mechanisms and relevance to human abuse and treatment. Brain Res Brain Res Rev 36:1-22, 2001.

94. Matthews RT, Yang L, Beal MF. S-Methylthiocitrulline, a neuronal nitric oxide synthase inhibitor, protects against malonate and MPTP neurotoxicity. Exp Neurol 143:282-286, 1997.
95. Zecca L, Tampellini D, Gatti A, Crippa R, Eisner M, Sulzer D et al. The neuromelanin of human substantia nigra and its interaction with metals. J Neural Transm 109:663-672, 2002.

96. Berg D, Gerlach M, Youdim MB, Double KL, Zecca L, Riederer $\mathrm{P}$ et al. Brain iron pathways and their relevance to Parkinson's disease. J Neurochem 79:225-236, 2001.

97. Sulzer D, Bogulavsky J, Larsen KE, Behr G, Karatekin E, Kleinman $\mathrm{MH}$ et al. Neuromelanin biosynthesis is driven by excess cytosolic catecholamines not accumulated by synaptic vesicles. Proc Natl Acad Sci USA 97:11869-11874, 2000.

98. Larsen KE, Sulzer D. Autophagy in neurons: a review. Histol Histopathol 17:897-908, 2002.

99. Liu Y, Peter D, Roghani A, Schuldiner S, Prive GG, Eisenberg D et al. A cDNA that suppresses MPP + toxicity encodes a vesicular amine transporter. Cell 70:539-551, 1992.

100. Pothos EN, Larsen KE, Krantz DE, Liu Y-J, Edwards RH, Sulzer D. Synaptic vesicle transporter expression regulates vesicle phenotype and quantal size. J Neurosci 20:7297-7306, 2000.

101. Larsen KE, Fon E, LaVoie M, Hastings TG, Edwards RH, Sulzer D. Methamphetamine-induced degeneration of dopaminergic neurons occurs via autophagy triggered by elevated cytosolic dopamine. J Neurosci 22:8951-8960, 2002.

102. Fumagalli F, Gainetdinov RR, Wang YM, Valenzano KJ, Miller GW, Caron MG. Increased methamphetamine neurotoxicity in heterozygous vesicular monoamine transporter 2 knock-out mice. J Neurosci 19:2424-2431, 1999.

103. Gainetdinov RR, Fumagalli F, Wang YM, Jones SR, Levey AI, Miller GW et al. Increased MPTP neurotoxicity in vesicular monoamine transporter 2 heterozygote knockout mice. J Neurochem 70:1973-1978, 1998

104. Cookson MR. Pathways to Parkinsonism. Neuron 37:7-10, 2003.

105. Yang Y, Nishimura I, Imai Y, Takahashi R, Lu B. Parkin suppresses dopaminergic neuron-selective neurotoxicity induced by pael-R in Drosophila. Neuron 37:911-924, 2003.

106. Ribeiro CS, Carneiro K, Ross CA, Menezes JR, Engelender S. Synphilin-1 is developmentally localized to synaptic terminals, and its association with synaptic vesicles is modulated by alphasynuclein. J Biol Chem 277:23927-23933, 2002.

107. Stefanis L, Larsen KE, Rideout HJ, Sulzer D, Greene LA. Expression of A53T mutant, but not wild-type, $\alpha$-synuclein in PC12 cells induces alterations of the ubiquitin-dependent degradation system, loss of dopamine release, and autophagic cell death. J Neurosci 21:9549-9560, 2001.

108. Cuervo AM, Dice JF. Lysosomes, a meeting point of proteins, chaperones, and proteases. $J$ Mol Med 76:6-12, 1998.

109. Iacopino A, Christakos S, German D, Sonsalla PK, Altar CA. Calbindin-D28K-containing neurons in animal models of neurodegeneration: possible protection from excitotoxicity. Brain Res Mol Brain Res 13:251-261, 1992.

110. Peter D, Liu Y, Sternini C, de Giorgio R, Brecha N, Edwards RH. Differential expression of two vesicular monoamine transporters. J Neurosci 15:6179-6188, 1995.

111. Staal RG, Hogan KA, Liang CL, German DC, Sonsalla PK. In vitro studies of striatal vesicles containing the vesicular monoamine transporter (VMAT2): rat versus mouse differences in sequestration of 1-methyl-4-phenylpyridinium. J Pharmacol Exp Ther 293:329-335, 2000.

112. Liss B, Neu A, Roeper J. The weaver mouse gain-of-function phenotype of dopaminergic midbrain neurons is determined by coactivation of wvGirk2 and K-ATP channels. J Neurosci 19: 8839-8848, 1999.

113. Burke RE, Antonelli M, Sulzer D. Glial cell line-derived neurotrophic growth factor inhibits apoptotic death of postnatal substantia nigra dopamine neurons in primary culture. $J$ Neurochem 71:517-525, 1998.

114. Offen D, Elkon H, Melamed E. Apoptosis as a general cell death pathway in neurodegenerative diseases. J Neural Transm Suppl 58:153-166, 2000.

115. Przedborksi S, Vila M. MPTP: a review of its mechanisms of neurotoxicity. Clin Neurosci Res 1:407-418, 2001.

116. Vila M, Jackson-Lewis V, Guegan C, Wu DC, Teismann P, Choi DK et al. The role of glial cells in Parkinson's disease. Curr Opin Neurol 14:483-489, 2001. 
117. Wilms H, Rosenstiel P, Sievers J, Deuschl G, Zecca L, Lucius R. Activation of microglia by human neuromelanin is NF- $\kappa \mathrm{B}$ dependent and involves p38 mitogen-activated protein kinase: implications for Parkinson's disease. FASEB J 17:500-502, 2003.

118. Teismann P, Tieu K, Choi DK, Wu DC, Naini A, Hunot $\mathrm{S}$ et al. Cyclooxygenase-2 is instrumental in Parkinson's disease neurodegeneration. Proc Natl Acad Sci USA 100:5473-5478, 2003.

119. Parkinson Study Group. Effect of deprenyl on the progression of disability in early Parkinson's disease. N Engl J Med 321:1364_ 1371, 1989.

120. Parkinson Study Group. Effects of tocopherol and deprenyl on the progression of disability in early Parkinson's disease. $N$ Engl $J$ Med 328:176-183, 1993.

121. Myllyla VV, Sotaniemi KA, Vuorinen JA, Heinonen E. Selegiline as initial treatment in de novo parkinsonian patients. Neurology 42:339-343, 1992.

122. Palhagen S, Heinonen EH, Hagglund J, Kaugesaar T, Kontants H, Maki-Ikola $\mathrm{O}$ et al. Selegiline delays the onset of disability in de novo parkinsonian patients. Swedish Parkinson Study Group. Neurology, 51:520-525, 1998.

123. Giladi N, McDermott MP, Fahn S, Przedborski S, Jankovic J, Stern $\mathrm{M}$ et al. Freezing of gait in PD: prospective assessment in the DATATOP cohort. Neurology 56:1712-1721, 2001.

124. Shoulson I, Oakes D, Fahn S, Lang A, Langston JW, LeWitt P et al. Impact of sustained deprenyl (selegiline) in levodopa-treated Parkinson's disease: a randomized placebo-controlled extension of the deprenyl and tocopherol antioxidative therapy of parkinsonism trial. Ann Neurol 51:604-612, 2002.

125. Beal MF. Excitotoxicity and nitric oxide in Parkinson's disease pathogenesis. Ann Neurol 44:S110-S114, 1998.

126. Benazzouz A, Boraud T, Dubedat P, Boireau A, Stutzmann JM, Gross C. Riluzole prevents MPTP-induced parkinsonism in the rhesus monkey: a pilot study. Eur J Pharmacol 284:299-307, 1995.

127. Barneoud P, Mazadier M, Miquet JM, Parmentier S, Dubedat P, Doble A et al. Neuroprotective effects of riluzole on a model of Parkinson's disease in the rat. Neuroscience 74:971-983, 1996.

128. Boireau A, Dubedat P, Bordier F, Imperato A, Moussaoui S. The protective effect of riluzole in the MPTP model of Parkinson's disease in mice is not due to a decrease in $\operatorname{MPP}(+)$ accumulation. Neuropharmacology 39:1016-1020, 2000.

129. Obinu MC, Reibaud M, Blanchard V, Moussaoui S, Imperato A. Neuroprotective effect of riluzole in a primate model of Parkinson's disease: behavioral and histological evidence. Mov Disord 17:13-19, 2002.

130. Jankovic J, Hunter C. A double-blind, placebo-controlled and longitudinal study of riluzole in early Parkinson's disease. Parkinsonism Relat Disord 8:271-276, 2002.

131. Rascol O, Olanow W, Brooks D, Koch G, Truffinet P, Bejuit R. Effect of riluzole on Parkinson's disease progression: a double-blind placebo-controlled study. Neurology 60[Suppl 1]:A288, 2003.

132. Pothos E, Davila V, Sulzer D. Presynaptic recording of quanta from midbrain dopamine neurons and modulation of the quantal size. J Neurosci 18:4106-4118, 1998.

133. Gash DM, Zhang Z, Ovadia A, Cass WA, Yi A, Simmerman L et al. Functional recovery in parkinsonian monkeys treated with GDNF. Nature 21:252-255, 1996.

134. Grondin R, Zhang Z, Yi A, Cass WA, Maswood N, Andersen AH et al. Chronic, controlled GDNF infusion promotes structural and functional recovery in advanced parkinsonian monkeys. Brain 125:2191-2201, 2002.

135. Nutt JG, Burchiel KJ, Comella CL, Jankovic J, Lang AE, Laws ER $\mathrm{Jr}$ et al. Randomized, double-blind trial of glial cell line-derived neurotrophic factor (GDNF) in PD. Neurology 60:69-73, 2003.

136. Gill SS, Patel NK, O'Sullivan K, Brooks DJ, Hotton GR, Svendsen $\mathrm{C}$ et al. Intraparenchymal putaminal administration of glialderived neurotrophic factor in the treatment of advanced Parkinson's disease. Neurology 58[Suppl 3]:A241, 2002.

137. Kordower JH, Emborg ME, Bloch J, Ma SY, Chu Y, Leventhal L et al. Neurodegeneration prevented by lentiviral vector delivery of GDNF in primate models of Parkinson's disease. Science 290:767-773, 2000

138. Steiner JP, Hamilton GS, Ross DT, Valentine HL, Guo H, Connolly MA et al. Neurotrophic immunophilin ligands stimulate structural and functional recovery in neurodegenerative animal models. Proc Natl Acad Sci USA 94:2019-2024, 1997.

139. Guo X, Dawson VL, Dawson TM. Neuroimmunophilin ligands exert neuroregeneration and neuroprotection in midbrain dopaminergic neurons. Eur J Neurosci, 13:1683-1693, 2001.

140. Tanaka K, Fujita N, Yoshioka M, Ogawa N. Immunosuppressive and non-immunosuppressive immunophilin ligands improve $\mathrm{H}(2) \mathrm{O}(2)$-induced cell damage by increasing glutathione levels in NG108-15 cells. Brain Res 889:225-228, 2001.

141. Tanaka K, Yoshioka M, Miyazaki I, Fujita N, Ogawa N. GPI1046 prevents dopaminergic dysfunction by activating glutathione system in the mouse striatum. Neurosci Lett 321:45-48, 2002.

142. Harper S, Bilsland J, Young L, Bristow L, Boyce S, Mason G et al. Analysis of the neurotrophic effects of GPI-1046 on neuron survival and regeneration in culture and in vivo. Neuroscience 88:257-267, 1999.

143. Bocquet A, Lorent G, Fuks B, Grimee R, Talaga P, Daliers J et al. Failure of GPI compounds to display neurotrophic activity in vitro and in vivo. Eur J Pharmacol 415:173-180, 2001.

144. Emborg ME, Shin P, Roitberg B, Sramek JG, Chu Y, Stebbins GT et al. Systemic administration of the immunophilin ligand GPI 1046 in MPTP-treated monkeys. Exp Neurol 168:171-182, 2001.

145. Eberling JL, Pivirotto P, Bringas J, Steiner JP, Kordower JH, Chu Y et al. The immunophilin ligand GPI-1046 does not have neuroregenerative effects in MPTP-treated monkeys. Exp Neurol 178:236-242, 2002.

146. Schapira AH, Mann VM, Cooper JM, Dexter D, Daniel SE, Jenner P et al. Anatomic and disease specificity of NADH CoQ1 reductase (complex I) deficiency in Parkinson's disease. $J$ Neurochem 55:2142-2145, 1990.

147. Shults CW, Haas RH, Passov D, Beal MF. Coenzyme Q(10) levels correlate with the activities of complexes I and II/III in mitochondria from parkinsonian and nonparkinsonian subjects. Ann Neurol 42:261-264, 1997.

148. Matsubara T, Azuma T, Yoshida S, Yamagami T. Serum coenzyme Q10 level in Parkinson syndrome. In: Biomedical and clinical aspects of coenzyme Q10 (Folkers K, Littarru GP, Yamagami T, eds), pp 159-166. New York: Elsevier Science, 1991.

149. Matthews RT, Yang L, Browne S, Baik M, Beal MF. Coenzyme Q10 administration increases brain mitochondrial concentrations and exerts neuroprotective effects. Proc Natl Acad Sci USA, 95:8892-8897, 1998

150. Shults CW, Oakes D, Kieburtz K, Beal MF, Haas R, Plumb S et al. Effects of coenzyme Q(10) in early Parkinson disease - Evidence of slowing of the functional decline. Arch Neurol 59:15411550, 2002.

151. Beal MF. Bioenergetic approaches for neuroprotection in Parkinson's disease. Ann Neurol 53[Suppl 3]:S39-S47; discussion S47-S48, 2003.

152. Du Y, Ma Z, Lin S, Dodel RC, Gao F, Bales KR et al. Minocycline prevents nigrostriatal dopaminergic neurodegeneration in the MPTP model of Parkinson's disease. Proc Natl Acad Sci USA 98:14669-14674, 2001.

153. Wu D, Jackson-Lewis V, Vila M, Tieu K, Teismann P, Vadseth $\mathrm{C}$ et al. Blockade of microglial activation is neuroprotective in the 1-methyl-4-phenyl-1,2,3,6-tetrahydropyridine mouse model of Parkinson disease. J Neurosci 22:1763-1771, 2002.

154. Tatton WG. Selegiline can mediate neuronal rescue rather than neuronal protection. Mov Disord 8:S20-S30, 1993.

155. Waldmeier PC, Spooren WP, Hengerer B. CGP 3466 protects dopaminergic neurons in lesion models of Parkinson's disease. Naunyn Schmiedebergs Arch Pharmacol 362:526-537, 2000.

156. Markey SP, Johannessen JN, Chiueh CC, Burns RS, Herkenham MA. Intraneuronal generation of a pyridinium metabolite may cause drug-induced parkinsonism. Nature 311:464-467, 1984.

157. Javitch JA, D'Amato RJ, Strittmatter SM, Snyder SH. Parkinsonism-inducing neurotoxin, N-methyl-4-phenyl-1,2,3,6-tetrahydropyridine: uptake of the metabolite $\mathrm{N}$-methyl-4-phenylpyridine by dopamine neurons explains selective toxicity. Proc Natl Acad Sci USA 82:2173-2177, 1985 .

158. Duyckaerts C. Images. Les corps et prolongements de Lewy. Rev Neurol (Paris) 156:800-801, 2000. 